\title{
An optimized multi-proxy, multi-site Antarctic ice and gas orbital chronology (AICC2012): 120-800 ka
}

\author{
L. Bazin ${ }^{1}$, A. Landais ${ }^{1}$, B. Lemieux-Dudon ${ }^{2}$, H. Toyé Mahamadou Kele ${ }^{2}$, D. Veres ${ }^{3,4}$, F. Parrenin ${ }^{3}$, P. Martinerie ${ }^{3}$, \\ C. Ritz $^{3}$, E. Capron ${ }^{5}$, V. Lipenkov ${ }^{6}$, M.-F. Loutre ${ }^{7}$, D. Raynaud ${ }^{3}$, B. Vinther ${ }^{8}$, A. Svensson ${ }^{8}$, S. O. Rasmussen ${ }^{8}$, \\ M. Severi ${ }^{9}$, T. Blunier ${ }^{8}$, M. Leuenberger ${ }^{10}$, H. Fischer ${ }^{10}$, V. Masson-Delmotte ${ }^{1}$, J. Chappellaz $^{3}$, and E. Wolff ${ }^{5}$ \\ ${ }^{1}$ Laboratoire des Sciences du Climat et de l'Environnement, UMR8212, CNRS - Gif sur Yvette, France \\ ${ }^{2}$ Laboratoire Jean Kuntzmann, Grenoble, France \\ ${ }^{3}$ Laboratoire de Glaciologie et Geophysique de l'Environnement, CNRS-UJF, St. Martin d'Heres, France \\ ${ }^{4}$ Institute of Speleology, Romanian Academy, Cluj-Napoca, Romania \\ ${ }^{5}$ British Antarctic Survey, Cambridge, UK \\ ${ }^{6}$ Arctic and Antarctic Research Institute, St. Petersburg, Russia \\ ${ }^{7}$ Université catholique de Louvain, Earth and Life Institute, Georges Lemaitre Center for Earth and Climate Research, \\ Louvain-la-Neuve, Belgium \\ ${ }^{8}$ Centre for Ice and Climate, Niels Bohr Institute, University of Copenhagen, Copenhagen, Denmark \\ ${ }^{9}$ Department of Chemistry Ugo Schiff, University of Florence, Florence, Italy \\ ${ }^{10}$ Climate and Environmental Physics, Physics Institute and Oeschger Center for Climate Change Research, \\ University of Bern, Bern, Switzerland
}

Correspondence to: L. Bazin (lucie.bazin@1sce.ipsl.fr), A. Landais (alandais@1sce.ipsl.fr)

Received: 14 November 2012 - Published in Clim. Past Discuss.: 30 November 2012

Revised: 24 June 2013 - Accepted: 25 June 2013 - Published:

\begin{abstract}
An accurate and coherent chronological framework is essential for the interpretation of climatic and environmental records obtained from deep polar ice cores. Until now, one common ice core age scale had been developed based on an inverse dating method (Datice), combining glaciological modelling with absolute and stratigraphic markers between 4 ice cores covering the last $50 \mathrm{ka}$ (thousands of years before present) (Lemieux-Dudon et al., 2010). In this paper, together with the companion paper of Veres et al. (2013), we present an extension of this work back to $800 \mathrm{ka}$ for the NGRIP, TALDICE, EDML, Vostok and EDC ice cores using an improved version of the Datice tool. The AICC2012 (Antarctic Ice Core Chronology 2012) chronology includes numerous new gas and ice stratigraphic links as well as improved evaluation of background and associated variance scenarios. This paper concentrates on the long timescales between 120-800 ka. In this framework, new measurements of $\delta^{18} \mathrm{O}_{\text {atm }}$ over Marine Isotope Stage (MIS) 11-12 on EDC and a complete $\delta^{18} \mathrm{O}_{\text {atm }}$ record of the TALDICE ice cores permit us to derive additional orbital gas age constraints. The coherency of the different
\end{abstract}

orbitally deduced ages (from $\delta^{18} \mathrm{O}_{\mathrm{atm}}, \delta \mathrm{O}_{2} / \mathrm{N}_{2}$ and air content) has been verified before implementation in AICC2012. The new chronology is now independent of other archives and shows only small differences, most of the time within the original uncertainty range calculated by Datice, when compared with the previous ice core reference age scale EDC3, the Dome F chronology, or using a comparison between speleothems and methane. For instance, the largest deviation between AICC2012 and EDC3 (5.4 ka) is obtained around MIS 12. Despite significant modifications of the chronological constraints around MIS 5, now independent of speleothem records in AICC2012, the date of Termination II is very close to the EDC3 one.

\section{Introduction}

While ice core records offer a wealth of palaeoclimatic and paleoenvironmental information, uncertainties associated with ice core dating limit their contribution to the understanding of past climate dynamics. Age scales in calendar 
years have been constructed for Greenland ice cores thanks to layer counting in sites offering sufficient accumulation rates (GRIP, NGRIP) (Rasmussen et al., 2006; Svensson et al., 2006; Svensson et al., 2008), allowing the construction of the GICC05 Greenland age scale currently spanning the past $60 \mathrm{ka}$ (i.e. thousand of years before present, present being year $1950 \mathrm{AD}$ in our study). Layer counting is not possible for deep Antarctic ice cores recovered in low accumulation areas and absolute time markers are generally lacking for these long Antarctic records, now extending to $800 \mathrm{ka}$. Exceptions are promising studies using ${ }^{40} \mathrm{Ar} /{ }^{39} \mathrm{Ar}$ and U/Th dating tools (Dunbar et al., 2008; Aciego et al., 2011) as well as links between ${ }^{10} \mathrm{Be}$ peaks and well-dated magnetic events (Raisbeck et al., 2007) but an absolute age scale for the last $800 \mathrm{ka}$ is still missing. As a result, dating of the deepest part of these Antarctic cores is largely based on various approaches combining ice flow modelling with orbital tuning.

Initial orbital dating in ice cores was inspired by orbital dating of marine cores (Imbrie and Imbrie, 1980), assuming that the Milanković theory (1941), linking ice volume and high latitude insolation, is correct. A similar link has been proposed between temperature records from water isotopes and the insolation curves deduced from orbital parameters (obliquity, precession) (Lorius et al., 1985). The imprint of precession in the Vostok ice core record of methane $\left(\mathrm{CH}_{4}\right)$ concentration was also investigated (Ruddiman and Raymo, 2003). Such assumptions are, however, not satisfactory when one important question is to identify the insolation-climate phase relationship at orbital timescales. More recently, three different orbital dating approaches have been developed for ice core dating, independent of Antarctic climate or greenhouse gases records.

First, long records of $\delta^{18} \mathrm{O}$ of atmospheric $\mathrm{O}_{2}\left(\delta^{18} \mathrm{O}_{\mathrm{atm}}\right)$ have revealed that this parameter is highly correlated with insolation variations in the precession band with a lag of about 5-6 ka (Bender et al., 1994; Petit et al., 1999; Dreyfus et al., 2007). Studies have linked variations in precession to $\delta^{18} \mathrm{O}_{\text {atm }}$ through changes in the low latitude water cycle and biospheric productivity (Bender et al., 1994; Malaizé et al., 1999; Wang et al., 2008; Severinghaus et al., 2009; Landais et al., 2007, 2010). The significant time delay between changes in precession and changes in $\delta^{18} \mathrm{O}_{\mathrm{atm}}$ has been attributed to a combination of the 1-2 ka residence time of $\mathrm{O}_{2}$ in the atmosphere (Bender et al., 1994; Hoffmann et al., 2004) and to the numerous and complex processes linking the isotopic composition of seawater to atmospheric oxygen via the dynamic response of the tropical water cycle to precession forcing and the associated variations in terrestrial and oceanic biospheres (Landais et al., 2010, and references therein). This multiplicity of processes also suggests that lags may vary with time (Jouzel et al., 2002; Leuenberger, 1997). As a consequence, the $\delta^{18} \mathrm{O}_{\text {atm }}$ record from long ice cores can be used to constrain ice core chronologies, but with a large associated uncertainty (6 ka) (Petit et al., 1999; Dreyfus et al., 2007).
Second, Bender (2002) has proposed that the elemental ratio $\delta \mathrm{O}_{2} / \mathrm{N}_{2}$ in the trapped air could be used as a new orbital tuning tool. Indeed, $\delta \mathrm{O}_{2} / \mathrm{N}_{2}$ measurements in the firn near the pore close-off depth (about $100 \mathrm{~m}$ below the ice-sheet surface, i.e. where unconsolidated snow is compressed and lock the air in) have revealed that the air trapping process is associated with a relative loss of $\mathrm{O}_{2}$ with respect to $\mathrm{N}_{2}$ (Battle et al., 1996; Severinghaus and Battle, 2006; Huber et al., 2006). Between 160 and $400 \mathrm{ka}$, the $\delta \mathrm{O}_{2} / \mathrm{N}_{2}$ record of the Vostok ice core displays variations similar to those of the local 21 December insolation $\left(78^{\circ} \mathrm{S}\right)$. From these two observations, Bender (2002) formulated the hypothesis that local Antarctic summer insolation influences near-surface snow metamorphism and that this signature is preserved during the firnification process down to the pore close-off depth, where it modulates the loss of $\mathrm{O}_{2}$. From this hypothesis, he proposed the use of $\delta \mathrm{O}_{2} / \mathrm{N}_{2}$ for dating purposes and this approach was used by Kawamura et al. (2007) and Suwa and Bender (2008) to construct orbital chronologies of the Dome $\mathrm{F}$ and Vostok ice cores back to 360 and $400 \mathrm{ka}$, respectively. Using their high-quality $\delta \mathrm{O}_{2} / \mathrm{N}_{2}$ record on the Dome F ice core and comparison with radiometric dating obtained on speleothem records, Kawamura et al. (2007) estimated the dating uncertainty to be as low as $0.8-2.9 \mathrm{ka}$. Still, Landais et al. (2012) have suggested that the uncertainty could be higher in some cases because (1) the tuning target is questionable and (2) the match between the $\delta \mathrm{O}_{2} / \mathrm{N}_{2}$ and insolation signal may not always be straightforward in periods characterized by low eccentricity. Moreover, no consistent theory has been put forward that can explain how the insolation signal imprinted in the snow pack survives the densification process.

Third, additional orbital information was derived from local insolation changes imprinted in the record of total air content in polar ice. Raynaud et al. (2007) indeed showed that part of the variance in total air content in the EPICA Dome $\mathrm{C}$ (EDC) ice core over the last $440 \mathrm{ka}$ can be explained by the variations of an integrated summer insolation parameter (i.e. summation over the year of the daily insolation exceeding some threshold for a given latitude) that has a dominant obliquity component. This marker was therefore suggested as another tool for orbital dating of ice core records.

When avoiding the use of climate records as orbital targets, three orbital tools $\left(\delta^{18} \mathrm{O}_{\mathrm{atm}}, \delta \mathrm{O}_{2} / \mathrm{N}_{2}\right.$ and air content) are available for deep ice cores dating. These three tools have different tuning targets and are associated with at least two different mechanisms (local insolation influencing air trapping and precession influencing hydrological cycle and biosphere productivity). They should thus provide independent information and should be used as complementary tools in ice core dating. The full coherency between these orbital age markers still remains to be examined. So far, Suwa and Bender (2008) explored the complementarity of $\delta^{18} \mathrm{O}_{\text {atm }}$ and $\delta \mathrm{O}_{2} / \mathrm{N}_{2}$ and Lipenkov et al. (2011) the one of $\delta \mathrm{O}_{2} / \mathrm{N}_{2}$ and air content at Vostok between 100 and $400 \mathrm{ka}$. 
The first integrated dating effort for a deep Antarctic ice core combining glaciological modelling and absolute and orbital tuning was conducted for the Vostok ice core (Petit et al., 1999; Parrenin et al., 2001, 2004). Longer ice core climatic and greenhouse gases records have been obtained from the EDC ice core that covers the last $800 \mathrm{ka}$ (Jouzel et al., 2007; Lüthi et al., 2008; Loulergue et al., 2008). The state of the art dating of the EDC ice core (EDC3 chronology) has been described in Parrenin et al. (2007). It is based on ice flow modelling using an inverse method constrained by various age markers. These age markers include reference horizons such as volcanic horizons (Mt. Berlin eruption, Dunbar et al., 2008) and peaks in ${ }^{10} \mathrm{Be}$ flux (i.e. Laschamp event, Yiou et al., 1997; Raisbeck et al., 2007). The EDC3 age scale was synchronized with the layer-counted Greenland GICC05 chronology over the last $6 \mathrm{ka}$, the deglaciation and the Laschamp event through 5 age constraints. Other tie points are more subject to discussion because they have underlying assumptions that some climatic events are synchronous, for example the abrupt methane increase at Termination II was assumed to be synchronous (within $2 \mathrm{ka}$ ) with the abrupt $\delta^{18} \mathrm{O}$ shift in speleothem calcite recorded in the East Asia (Yuan et al., 2004) and Levantine (Bar-Matthews et al., 2003) regions at around $130.1 \mathrm{ka}$.

For ice older than the last interglacial period, tie points were mainly derived from orbital tuning. Thirty-eight (38) $\delta^{18} \mathrm{O}_{\text {atm }}$ tie points with a $6 \mathrm{ka}$ uncertainty were included in EDC 3 between 400 and $800 \mathrm{ka}$ as well as 10 air content tie points with a $4 \mathrm{ka}$ uncertainty between 71 and $431 \mathrm{ka}$. The overall uncertainty attached to the EDC3 timescale was estimated at $6 \mathrm{ka}$ from $130 \mathrm{ka}$ down to the bottom of the record (Parrenin et al., 2007).

The EPICA Dronning Maud Land (EDML) timescale over the past $150 \mathrm{ka}$ has been derived directly from the EDC3 timescale after matching volcanic horizons between the two cores (Ruth et al., 2007). The TALos Dome ICE core (TALDICE) timescale has also been derived from other Antarctic ice cores through synchronization of the $\mathrm{CH}_{4}$ records (Buiron et al., 2011; Schüpbach et al., 2011), $\mathrm{CH}_{4}$ being with $\delta^{18} \mathrm{O}_{\text {atm }}$ a global tracer of the atmosphere, hence of wide use for relative dating of ice cores (e.g. Capron et al., 2010).

Summarizing, each deep ice core has its own chronology which is not necessarily coherent with the other ice core chronologies. Typically, the Vostok GT4 and Dome C EDC3 age scales have been established separately and display significant deviations (Parrenin et al., 2007). Since some proxies are measured on the ice phase, such as water isotopes, dust or chemical species, and other in the gas phase, for example $\mathrm{CO}_{2}$ and $\mathrm{CH}_{4}$, ice and gas age scales must be established. The ice and gas timescales are different because air is isolated from the surface at approximately $50-120 \mathrm{~m}$ under the ice-sheet surface, at the firn-ice transition, or lock-in depth (LID). In addition to the ice chronology, it is thus essential to have for each ice core a good estimate of the depth evolution of the LID to link gas and ice chronologies. According to firnification models (Herron and Langway, 1980; Schwander et al., 1993; Arnaud et al., 2000; Goujon et al., 2003; Salamatin et al., 2004), the LID evolution can be estimated from past changes in temperature and accumulation rate. The outputs of firnification models have thus classically been used to calculate the LID and provide the gas chronology associated with the ice chronology. However, firnification models have recently been reported to be inaccurate for representing glacial-interglacial changes in LID in Antarctica (Parrenin et al., 2012a; Capron et al., 2013).

Recently, Lemieux-Dudon et al. (2010) developed a method based on an inverse technique to produce coherent ice and gas timescales for 4 different ice cores (Vostok, EDC, EDML, NGRIP). This method aims for the best compromise between individual chronological information for each ice core using glaciological modelling and gas and ice absolute or relative markers. This consistent timescale only covers the last $50 \mathrm{ka}$ (where age markers were compiled and implemented) and does not include all deep ice cores.

In this paper, together with the companion paper of Veres et al. (2013), we aim at producing a coherent ice and gas timescale over the last $800 \mathrm{ka}$ including 5 ice cores (Vostok, EDC, EDML, TALDICE, NGRIP) without any assumption on the synchronism between climatic records and insolation or speleothem-derived tie points. We use the same strategy as the one of Lemieux-Dudon et al. (2010) with some technical and methodological (SOM) improvements. In order to include the TALDICE ice core and extend the timescale prior to $50 \mathrm{ka}$, we gather a database of age markers and expand $\delta^{18} \mathrm{O}_{\mathrm{atm}}$ records of TALDICE and EDC. We then discuss the implementation and robustness of orbital points that are key for the long timescales. Finally, we discuss the climatic implications of this new timescales with $\delta^{18} \mathrm{O}_{\text {ice }}$ and $\mathrm{CH}_{4}$ records displayed on the new chronology over the last $800 \mathrm{ka}$ with a focus on the last interglacial period (Marine Isotopic Stage, MIS 5).

\section{Dating strategy}

The Datice tool (Lemieux-Dudon et al., 2010) is a numerical program that permits us to obtain the best compromise between a background chronology (based on modelling of snow accumulation rates, snow densification into ice and ice flow) and observations (absolute ages or certain reference horizons, stratigraphic links between several cores or also orbital ages).

Basically, a background scenario consists of three profiles along the ice core as a function of the depth $z$ : the initial accumulation rate $(A)$, the vertical thinning function $(\tau)$ and the Lock-In Depth in Ice Equivalent (LIDIE). Age scales for the ice matrix $(\psi)$ and the gas bubbles $(\chi)$, which is assumed to be unique and the same for all species, are deduced using the following equations: 
$\psi(z)=\int_{0}^{z} \frac{D\left(z^{\prime}\right)}{\tau\left(z^{\prime}\right) \cdot A\left(z^{\prime}\right)} \mathrm{d} z^{\prime}$

$\Delta \operatorname{depth}(z) \sim \operatorname{LIDIE}(z) \cdot \tau(z)$

$\chi(z)=\psi(z-\Delta \operatorname{depth}(z))$,

where $D$ is the relative density of the snow/ice material.

In the Datice tool, one needs to define how confident we are in the background scenarios, by determining confidence intervals (errors are assumed to be log-normal) on the accumulation, thinning and LIDIE profiles and also correlation lengths for each of these profiles (the errors in between profiles are assumed to be decorrelated). The same is true for the observations (absolute age horizons or stratigraphic links between the cores), which are assumed independent and for which a confidence interval is assigned. The Datice tool then finds the best scenario of accumulation, thinning and LIDIE and the resulting ice and gas chronologies by taking into account the background scenarios and the observations. The Datice methodology relies on the construction of a cost function, which takes into account the full dating information (background scenarios and observations). The best scenario is the one which satisfies more closely all the dating constraints. The search for the best scenario is driven by a quasinewton algorithm (Gilbert and Lemarechal, 1993), which requires a linearization of the model equations (in order to calculate the gradient of the cost function) at each iteration.

The estimate of the age uncertainty is done exactly the same way as detailed in the SOM of Lemieux-Dudon et al. (2010). In summary, Datice calculates an error covariance matrix denoted $\mathbf{P}$, which is an estimate of the errors made on accumulation, thinning and LIDIE at each depth level and for each ice core. The $\mathbf{P}$ matrix entirely depends on inputs of the dating problem: the $\mathbf{B}$ matrix storing the covariances of errors of the different background scenarios (accumulation, thinning, LIDIE); the $\mathbf{R}$ matrix storing the uncertainties associated with each data constraint (absolute, stratigraphic, orbital tie points); and finally the $\boldsymbol{H}$ operator. $\boldsymbol{H}$ is the linearization of the observation operator, denoted $h$, that predicts the data (absolute, stratigraphic, orbital tie points) from a given scenario of accumulation, thinning and LIDIE. To illustrate this, the observation operator maps a vector $\left(a_{1}, \ldots, a_{n}, t_{1}, \ldots, t_{n}, l_{1}, \ldots, l_{n}\right)$ whose components are accumulation, thinning and LIDIE, into an age vector $\left(h_{1}, \ldots, h_{N}\right)$ that predicts the age at the age markers depths $\left(z_{1}, \ldots, z_{N}\right)$. Under some assumptions, $\mathbf{P}$ is expressed as: $\mathbf{P} \simeq\left(\mathbf{B}^{-1}+\boldsymbol{H}^{T} \mathbf{R}^{-1} \boldsymbol{H}\right)^{-1}$. The age error covariance matrix, $\mathbf{C}$, is expressed as: $\mathbf{C} \simeq \boldsymbol{H} \mathbf{P} \boldsymbol{H}^{T}$. $\mathbf{C}$ stores errors propagated from the background and observation variances and covariances. Near an absolute tie point with a small associated uncertainty, the a posteriori error will thus be dominated by the observation error, while near a tie point with a very large associated uncertainty, this error will mainly result from the variances (and covariances) associated with the background scenarios. More details on the age scale uncertainty calculation over different time periods are given in SOM.

After a revision of all the different age markers used in Lemieux-Dudon et al. (2010), we decided to remove the 6 orbital tuning points at Vostok $(132.4,200.6,246.0,293.6$, 336.2 and $373.8 \mathrm{ka}$; Parrenin et al., 2001) due to the climatic hypothesis they are based on, the isotopic points between TALDICE and EDC, the tie point at $130.1 \mathrm{ka}$ at EDC from speleothem dating and all points derived by successive transfer from one core to another. The air content data used for the construction of EDC3 (Parrenin et al., 2007) are replaced by new age markers (see Sect. 3).

Few absolute ages (tephra layers, Laschamp event, Brunhes-Matuyama reversal, layer counting) are available for the different ice cores. For tephra layers, we only consider the ones identified in our ice cores directly. As a consequence, we need orbital ages $\left(\delta^{18} \mathrm{O}_{\mathrm{atm}}, \delta \mathrm{O}_{2} / \mathrm{N}_{2}\right.$ and air content) with coherent uncertainties to constrain the timescale prior to $60 \mathrm{ka}$ when layer counting is not available. We use here available $\delta^{18} \mathrm{O}_{\mathrm{atm}}, \delta \mathrm{O}_{2} / \mathrm{N}_{2}$ and air content profiles on the different ice cores (Dreyfus et al., 2007, 2008; Suwa and Bender, 2008; Landais et al., 2012; Raynaud et al., 2007; Lipenkov et al., 2011) completed by new $\delta^{18} \mathrm{O}_{\text {atm }}$ data covering the period older than $50 \mathrm{ka}$ on the TALDICE ice core and the period $350-450 \mathrm{ka}$ on the EDC ice core.

The synchronization of the different ice cores is done through $\mathrm{CH}_{4}, \delta^{18} \mathrm{O}_{\text {atm }}$ measurements in the gas phase (255 tie points) and volcanic tie points in the ice phase (534 tie points) (Udisti et al., 2004; Severi et al., 2007, 2012; Loulergue et al., 2007; Lemieux-Dudon et al., 2010; Landais et al., 2006; Loulergue, 2007; Ruth et al., 2007; Buiron et al., 2011; Schüpbach et al., 2011; Capron et al., 2010; Schilt et al., 2010; Parrenin et al., 2012b; Svensson et al., 2013; Vinther et al., 2013, details in the SOM).

Additional constraints on the depth difference between a concomitant event in the ice and in the gas phases ( $\Delta$ depth) are available for Greenland ice cores over the millennial scale variability of the last glacial period (Dansgaard-Oeschger events) with the use of $\delta^{15} \mathrm{~N}$ in the air trapped in the ice. Each rapid warming is indeed recorded as a peak in $\delta^{15} \mathrm{~N}$ (thermal isotopic fractionation) in the gas phase and as a step in the ice $\delta^{18} \mathrm{O}$. The depth difference between the $\delta^{15} \mathrm{~N}$ peak and the ice $\delta^{18} \mathrm{O}$ step has been measured for DO 9-25 on the NorthGRIP ice core (Landais et al., 2004, 2005; Huber et al., 2006; Capron et al., 2010) defining 15 constraints for the $\Delta$ depth (Table in SOM).

Finally, it has been suggested that $\delta^{15} \mathrm{~N}$ in Antarctica can also be used for improving our estimate of LID independently of firnification models (Parrenin et al., 2012a). This is based on the assumption that the firn depth, from surface to the LID, is always equal to the depth of the diffusive zone, which can be inferred from $\delta^{15} \mathrm{~N}$ data. While this is very often the case for present day firns (Landais et al., 2006), a convective zone of about $20 \mathrm{~m}$ may exist during glacial period in remote sites of East Antarctica (Severinghaus et al., 2010). 
We thus refrain from imposing any delta-depth constraints from $\delta^{15} \mathrm{~N}$ profiles in Antarctica but use these data for the LIDIE background scenario (details in SOM).

\section{Orbital markers}

As discussed above, the most critical aspect for the 120 $800 \mathrm{ka}$ dating is the availability and use of the orbital markers. In a first sub-section, we will provide new $\delta^{18} \mathrm{O}_{\text {atm }}$ data for orbital constraints on TALDICE and EDC. In a second sub-section, we review and evaluate dating uncertainties of the available $\delta^{18} \mathrm{O}_{\mathrm{atm}}, \delta \mathrm{O}_{2} / \mathrm{N}_{2}$ and air content series.

\subsection{New measurements}

All measurements of $\delta^{18} \mathrm{O}_{\text {atm }}$ of air trapped in the ice cores of EDC and TALDICE were performed at LSCE, using a meltrefreeze method (Sowers et al., 1989; Landais et al., 2003a). The analyses were conducted on a Delta V plus (Thermo Electron Corporation) mass spectrometer and data were corrected for mass interferences (Severinghaus et al., 2001; Landais et al., 2003a). The measurements were calibrated against current dried exterior air. The $\delta^{18} \mathrm{O}_{\mathrm{atm}}$ is obtained after correction of the $\delta^{18} \mathrm{O}$ of $\mathrm{O}_{2}$ for the gravitational isotopic fractionation in the firn $\left(\delta^{18} \mathrm{O}_{\mathrm{atm}}=\delta^{18} \mathrm{O}-2 \delta^{15} \mathrm{~N}\right)$. The resulting data set has a precision of roughly $0.03 \%$ (1 sigma uncertainty).

\subsection{1 $\delta^{18} \mathbf{O}_{\text {atm }}$ of EDC}

The first EDC $\delta^{18} \mathrm{O}_{\text {atm }}$ record has been produced by Dreyfus et al. $(2007,2008)$ between 300 and $800 \mathrm{ka}$ with a mean resolution of $1.5 \mathrm{ka}$. They defined 38 tie points by aligning mid-slope variations of $\delta^{18} \mathrm{O}_{\text {atm }}$ with their counterparts in the precession parameter (delayed by $5 \mathrm{ka}$ ), leading to an uncertainty of $6 \mathrm{ka}$ for each tie point. Still, the period covering 300-410 ka and including MIS 11 shows $\delta^{18} \mathrm{O}_{\text {atm }}$ variations that cannot unambiguously match the precession curve (Fig. 1). During this period, the low eccentricity damps the variations of the climatic precession parameter, classically expressed as $e \sin (\bar{\omega})$ with $e$ the eccentricity and $\bar{\omega}$ the longitude of perihelion. During periods of low eccentricity, the mid-slope association is thus more difficult. As a consequence, the 6 tie points originally proposed over this period can be challenged.

We have performed $\delta^{18} \mathrm{O}_{\text {atm }}$ measurements on 92 new ice samples from EDC between 2479 and $2842 \mathrm{~m}$ (covering 300 to $500 \mathrm{ka}$ ) with a mean resolution of $1 \mathrm{ka}$.

With our improved resolution of the $\delta^{18} \mathrm{O}_{\text {atm }}$ signal over this period, we are now able to better constrain the EDC chronology by orbital tuning. To do so, we strictly follow the methodology of Dreyfus et al. (2007) described above. We obtain 7 new orbital tuned ages for the gas phase of EDC ice core, replacing the first 6 points of the Table 1 of Dreyfus et al. (2007). Finally, we end up with $39 \delta^{18} \mathrm{O}_{\text {atm }}$ points to

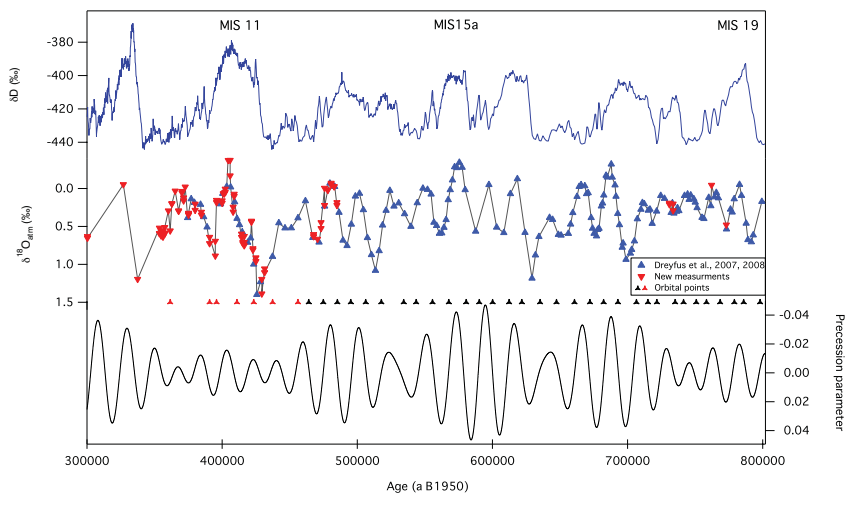

Fig. 1. EDC records between 300 and $800 \mathrm{ka}$ on the EDC3 age scale. Top: water stable isotope $(\delta \mathrm{D})$ record with labeling of selected interglacial periods (Jouzel et al., 2007). Middle: complete record of $\delta^{18} \mathrm{O}_{\text {atm }}$, blue triangles from Dreyfus et al. $(2007,2008)$ and red triangles from this study. Bottom: precession parameter (here on a reverse $y$ axis) obtained with the Analyseries software (Paillard et al., 1996), calculated using the Laskar et al. (2004) solution. Black points indicate the position of tie points between $\delta^{18} \mathrm{O}_{\mathrm{atm}}$ and precession parameter signals from Dreyfus et al. (2007); the red ones are from this study (Table 1).

be used as orbital constraints in the gas phase for the EDC ice core (Table 1). Note that the $\delta^{18} \mathrm{O}_{\mathrm{atm}}$ ages are in agreement with the absolute dating of the Brunhes-Matuyama reversal, suggesting that we did not miss any precession cycle (Dreyfus et al., 2008).

\subsection{2 $\delta^{18} \mathrm{O}_{\mathrm{atm}}$ of TALDICE}

Buiron et al. (2011) have measured the $\delta^{18} \mathrm{O}_{\mathrm{atm}}$ of TALDICE between 583 and $1402 \mathrm{~m}$ (9.4 and $125.8 \mathrm{ka})$ and could identify clear precession driven $\delta^{18} \mathrm{O}_{\mathrm{atm}}$ cycles around 10 and $85 \mathrm{ka}$. However significant gaps remained at $24-33 \mathrm{ka}, 81-$ $110 \mathrm{ka}$ and before $126 \mathrm{ka}$. With now 83 new depth levels measured in this study, we obtain a complete record of $\delta^{18} \mathrm{O}_{\mathrm{atm}}$ along the entire core with a mean resolution of $1.5 \mathrm{ka}$ (Fig. 2).

Using the original TALDICE 1a age scale (Buiron et al., 2011; Schüpbach et al., 2011), the full $\delta^{18} \mathrm{O}_{\text {atm }}$ record displays clear $\sim 23 \mathrm{ka}$ cycles corresponding to precession variations back to $200 \mathrm{ka}$ (Fig. 2). Prior to $200 \mathrm{ka}, \delta^{18} \mathrm{O}_{\mathrm{atm}}$ shows a large variability with much higher frequency variations. This questions the integrity of the record. Spurious variations of $\delta^{18} \mathrm{O}_{\text {atm }}$ can indeed be used, together with methane, to check the integrity of ice core records especially on their bottom part by comparison with undisturbed records of the same time period (Landais et al., 2003b). A comparison of the methane and $\delta^{18} \mathrm{O}_{\text {atm }}$ records of Vostok and TALDICE ice cores over the last $300 \mathrm{ka}$ on their respective chronologies (Fig. 3) shows significant differences. Over the last $150 \mathrm{ka}$, differences are most probably due to the different age scales of the ice cores since the $\mathrm{CH}_{4}$ and $\delta^{18} \mathrm{O}_{\mathrm{atm}}$ sequences and amplitudes are similar despite small shifts between the two 
Table 1. Orbital ages from $\delta^{18} \mathrm{O}_{\text {atm }}$ for EDC.

\begin{tabular}{cccc}
\hline Depth (m) & Gas age (ka) & $\sigma(k a)$ & Source \\
\hline 2644.44 & 363.094 & 6.0 & $\mathrm{a}$ \\
2697.23 & 389.425 & 6.0 & $\mathrm{a}$ \\
2708.24 & 398.546 & 6.0 & $\mathrm{a}$ \\
2751.13 & 408.283 & 6.0 & $\mathrm{a}$ \\
2777.54 & 427.377 & 6.0 & $\mathrm{a}$ \\
2795.31 & 435.854 & 6.0 & $\mathrm{a}^{*}$ \\
2812.79 & 454.779 & 6.0 & $\mathrm{a}$ \\
2819.2 & 464.557 & 6.0 & $\mathrm{~b}$ \\
2829.36 & 474.756 & 6.0 & $\mathrm{~b}$ \\
2841.75 & 485.293 & 6.0 & $\mathrm{~b}$ \\
2856.27 & 495.921 & 6.0 & $\mathrm{~b}$ \\
2872.56 & 506.642 & 6.0 & $\mathrm{~b}$ \\
2890.33 & 517.602 & 6.0 & $\mathrm{~b}$ \\
2913.3 & 532.027 & 6.0 & $\mathrm{~b} *$ \\
2921.99 & 545.313 & 6.0 & $\mathrm{~b}$ \\
2938.24 & 556.414 & 6.0 & $\mathrm{~b}$ \\
2968.08 & 567.606 & 6.0 & $\mathrm{~b}$ \\
2998.96 & 578.627 & 6.0 & $\mathrm{~b}$ \\
3008.93 & 589.460 & 6.0 & $\mathrm{~b}$ \\
3017.25 & 600.078 & 6.0 & $\mathrm{~b}$ \\
3027.54 & 610.875 & 6.0 & $\mathrm{~b}$ \\
3035.41 & 622.074 & 6.0 & $\mathrm{~b}$ \\
3043.01 & 634.419 & 6.0 & $\mathrm{~b}$ \\
3048.51 & 649.064 & 6.0 & $\mathrm{~b}$ \\
3056.77 & 660.789 & 6.0 & $\mathrm{~b}$ \\
3065.93 & 671.703 & 6.0 & $\mathrm{~b}$ \\
3077.74 & 682.326 & 6.0 & $\mathrm{~b}$ \\
3093.51 & 693.159 & 6.0 & $\mathrm{~b}$ \\
3112.43 & 703.964 & 6.0 & $\mathrm{~b}$ \\
3119.57 & 714.369 & 6.0 & $\mathrm{~b}$ \\
3124.27 & 724.376 & 6.0 & $\mathrm{~b}$ \\
3136.18 & 733.949 & 6.0 & $\mathrm{~b}$ \\
3143.2 & 741.944 & 6.0 & $\mathrm{~b}$ \\
3152.25 & 749.184 & 6.0 & $\mathrm{~b}$ \\
3158.91 & 758.069 & 6.0 & $\mathrm{~b}$ \\
3166.87 & 767.679 & 6.0 & $\mathrm{~b}$ \\
3174.81 & 777.607 & 6.0 & $\mathrm{~b}$ \\
3180.6 & 787.736 & 6.0 & $\mathrm{~b}$ \\
3189.83 & 797.460 & 6.0 & $\mathrm{~b}$ \\
\hline
\end{tabular}

a: this study. b: Dreyfus et al. (2007). The asterisks indicate tie points which have been removed (see Sect. 4.1).

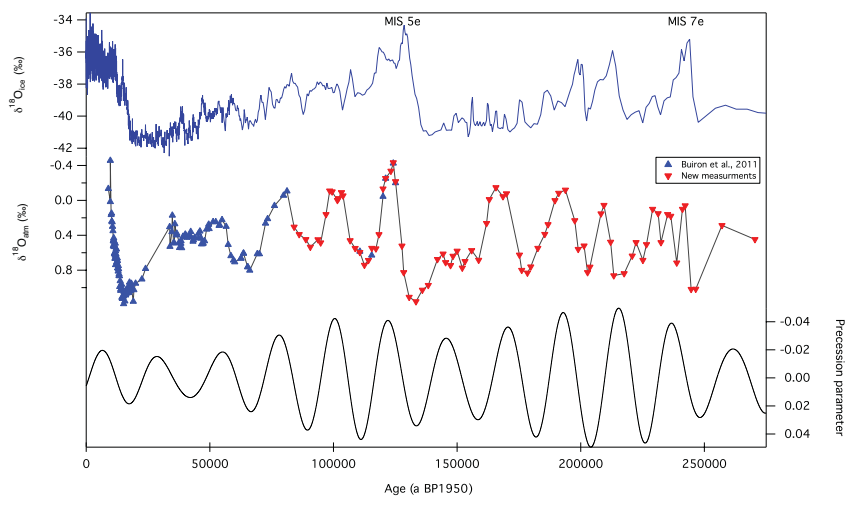

Fig. 2. TALDICE records between 0 and $250 \mathrm{ka}$ on TALDICE 1a age scale. Top: water stable isotope $\left(\delta^{18} \mathrm{O}_{\text {ice }}\right)$ record with labeling of selected interglacial periods (Stenni et al., 2011). Middle: complete record of $\delta^{18} \mathrm{O}_{\mathrm{atm}}$, blue triangles from Buiron et al. (2011) and red triangles from this study. Bottom: precession parameter (same as in Fig. 1).

Table 2. Stratigraphic links between TALDICE and Vostok deduced from $\delta^{18} \mathrm{O}_{\mathrm{atm}}$.

\begin{tabular}{lcc}
\hline $\begin{array}{l}\text { Depth } \\
\text { TALDICE }(\mathrm{m})\end{array}$ & $\begin{array}{c}\text { Depth } \\
\text { Vostok }(\mathrm{m})\end{array}$ & $\sigma(\mathrm{a})$ \\
\hline 668.93 & 310.5 & 1000 \\
1255.55 & 907 & 1000 \\
1308.39 & 1113 & 1000 \\
1333.37 & 1244 & 1000 \\
1357.95 & 1415 & 1500 \\
1373.99 & 1535 & 1500 \\
1390.4 & 1672.18 & 2000 \\
1406.27 & 1853.15 & 2000 \\
\hline
\end{tabular}

ice cores. Prior to $150 \mathrm{ka}$, the methane record has a poor resolution and the two $\delta^{18} \mathrm{O}_{\text {atm }}$ records show significant differences in amplitude and frequency before $200 \mathrm{ka}$. We have thus decided to stop analysis and chronologies at $150 \mathrm{ka}$ (corresponding to $\sim 1500 \mathrm{~m}$ depth) for the TALDICE ice core until new methane and $\delta^{18} \mathrm{O}_{\mathrm{atm}}$ measurements are performed allowing us to assess the integrity of the stratigraphy. Note that surprisingly large ice crystals have been observed below $1500 \mathrm{~m}$ on the TALDICE ice core, which further questions the integrity of the core.

By comparing TALDICE and Vostok $\delta^{18} \mathrm{O}_{\mathrm{atm}}$ records back to $150 \mathrm{ka}$, we were able to determine 8 new gas stratigraphic links between these two cores (Fig. 3 and Table 2).

\subsection{Orbital points database}

In this section, we combine the new orbital tie points derived in the previous section and the orbital tie points already available from previous studies. 


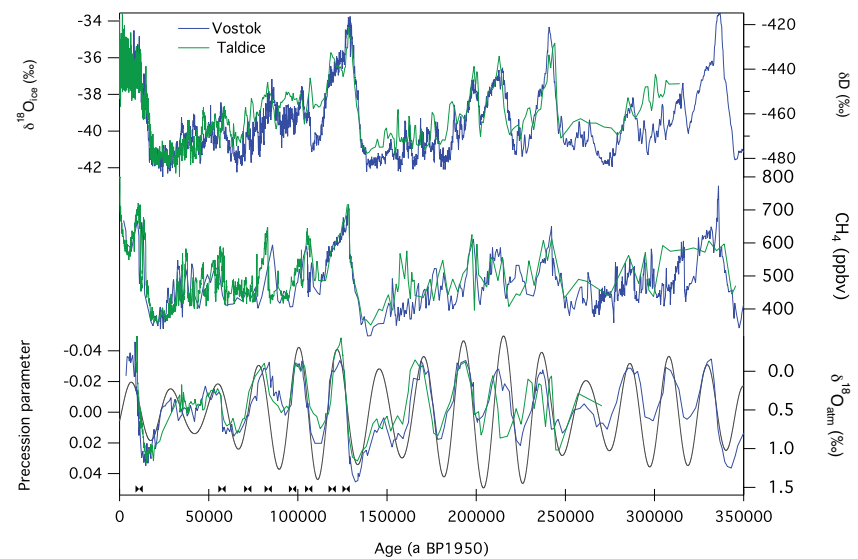

Fig. 3. Comparison between Vostok (blue) and TALDICE (green) ice cores on the $\delta^{18} \mathrm{O}_{\text {atm }}$ chronology (Bender, 2002) and TALDICE 1a age scale (Buiron et al., 2011; Schüpbach et al., 2011), respectively. Top: water stable isotope records $\left(\delta \mathrm{D}\right.$ and $\delta^{18} \mathrm{O}_{\text {ice }}$, respectively) (Petit et al., 1999; Stenni et al., 2011). Middle: methane records, Vostok: Petit et al. (1999); Caillon et al. (2003); Delmotte et al. (2004), TALDICE: Buiron et al. (2011); Schüpbach et al. (2011). Bottom: $\delta^{18} \mathrm{O}_{\mathrm{atm}}$ records: Vostok: Bender (2002); Suwa and Bender (2008), TALDICE: Buiron et al. (2011) and this study. The grey curve corresponds to the precession parameter. Black markers indicate the position of stratigraphic links between TALDICE and Vostok deduced from $\delta^{18} \mathrm{O}_{\mathrm{atm}}$ data.

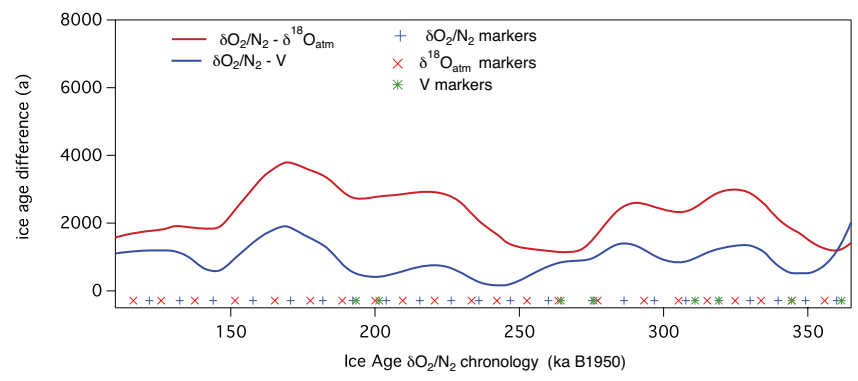

Fig. 4. Ice age difference between the $\delta \mathrm{O}_{2} / \mathrm{N}_{2}$ and air content (V) chronologies (blue) and $\delta \mathrm{O}_{2} / \mathrm{N}_{2}$ and $\delta^{18} \mathrm{O}_{\text {atm }}$ chronologies (red) on the Vostok ice core. The different markers show the position of the orbital age constraints for each chronology.

\subsection{1 $\delta^{18} \mathrm{O}_{\text {atm }}$}

In addition to the $\mathrm{EDC} \delta^{18} \mathrm{O}_{\mathrm{atm}}$ markers discussed above, we also use the markers deduced by Suwa and Bender (2008) for Vostok (Table 2 therein). The tuning is slightly different than the one chosen by Dreyfus et al. (2007) (tuning on the $65^{\circ} \mathrm{N}$ June insolation curve with a delay of $5.9 \mathrm{ka}$ instead of tuning on the precession signal with a $5 \mathrm{ka}$ delay). A comparison of both tuning strategies has shown that they are equivalent (Dreyfus et al., 2007).

Altogether, we now have a database of $\delta^{18} \mathrm{O}_{\text {atm }}$ with 39 gas age markers for EDC and 35 for Vostok. The uncertainty associated with all these points is estimated to be a quarter of
Table 3. Orbital ages from $\delta \mathrm{O}_{2} / \mathrm{N}_{2}$ for EDC, deduced from Landais et al. (2012).

\begin{tabular}{ccc}
\hline Depth $(\mathrm{m})$ & Ice age $(\mathrm{ka})$ & $\sigma(\mathrm{ka})$ \\
\hline 2795.69 & 449.000 & 4.0 \\
2808.33 & 460.000 & 4.0 \\
2818.15 & 470.000 & 4.0 \\
2829.13 & 480.000 & 4.0 \\
2841.58 & 490.000 & 4.0 \\
2858.78 & 501.000 & 4.0 \\
2873.06 & 512.000 & 4.0 \\
2888.95 & 522.000 & 4.0 \\
2905.88 & 533.000 & 4.0 \\
2919.62 & 551.000 & 4.0 \\
2936.61 & 562.000 & 4.0 \\
2975.52 & 573.000 & 4.0 \\
2999.23 & 583.000 & 4.0 \\
3009.36 & 594.000 & 4.0 \\
3017.73 & 605.000 & 4.0 \\
3028.6 & 616.000 & 4.0 \\
3065.86 & 677.000 & 4.0 \\
3078.05 & 688.000 & 4.0 \\
3092.52 & 698.000 & 4.0 \\
3109.93 & 710.000 & 4.0 \\
3169.32 & 778.000 & 6.0 \\
3179.27 & 788.000 & 6.0 \\
\hline
\end{tabular}

a precession period (Dreyfus et al., 2007), leading to a value of $6 \mathrm{ka}$. This relatively large uncertainty accounts for the uncertainty in the choice of the orbital target and for the fact that the shift between $\delta^{18} \mathrm{O}_{\mathrm{atm}}$ and precession is known to vary with time, especially over terminations (Jouzel et al., 2002; Kawamura et al., 2007).

\subsection{2 $\delta \mathrm{O}_{2} / \mathrm{N}_{2}$}

For the aim of the AICC2012 chronology, two $\delta \mathrm{O}_{2} / \mathrm{N}_{2}$ records are available: Vostok (100-400 ka, Suwa and Bender, 2008 ) and EDC (300 to $800 \mathrm{ka}$, Landais et al., 2012). While Suwa and Bender (2008) already produced $27 \delta \mathrm{O}_{2} / \mathrm{N}_{2}$ orbital tie points using as target the local December insolation, no tie points were proposed by Landais et al. (2012). Here, we have derived 20 orbital ages from the $\mathrm{EDC} \delta \mathrm{O}_{2} / \mathrm{N}_{2}$ record (Table 3). To do this, the $\delta \mathrm{O}_{2} / \mathrm{N}_{2}$ signal is filtered with a band pass between $1 / 15 \mathrm{ka}^{-1}$ and $1 / 100 \mathrm{ka}^{-1}$. Its mid slope variations are then associated with the mid-slopes of the local summer solstice insolation signal. No tie points were attributed in periods with too low $\delta \mathrm{O}_{2} / \mathrm{N}_{2}$ resolution and in periods without a clear correspondence between the $\delta \mathrm{O}_{2} / \mathrm{N}_{2}$ record and the insolation curve.

We have decided to attribute a conservative uncertainty of $4 \mathrm{ka}$ to all of these tie points (both for Vostok and EDC) because of the low quality of the measurements (gas loss) and questions about the phasing of local insolation curve and $\delta \mathrm{O}_{2} / \mathrm{N}_{2}$ curve (Suwa and Bender, 2008; Landais et al., 
Table 4. Orbital ages from air content for EDC, deduced from Raynaud et al. (2007).

\begin{tabular}{ccc}
\hline depth $(\mathrm{m})$ & ice age $(\mathrm{ka})$ & $\sigma(\mathrm{ka})$ \\
\hline 501.65 & 21.950 & 2.879 \\
693.668 & 38.950 & 2.211 \\
1255.93 & 86.950 & 3.082 \\
1377.67 & 100.950 & 4.031 \\
1790.29 & 142.950 & 6.468 \\
2086.69 & 202.950 & 6.403 \\
2186.29 & 216.950 & 6.316 \\
2307.2 & 245.950 & 6.316 \\
2350.1 & 260.950 & 6.615 \\
2500.25 & 306.950 & 6.652 \\
2510.75 & 318.950 & 6.242 \\
2610.8 & 346.950 & 7.120 \\
2632.25 & 359.950 & 6.576 \\
2783.5 & 424.950 & 6.782 \\
\hline
\end{tabular}

2012). Note that choosing a smaller uncertainty for the $\delta \mathrm{O}_{2} / \mathrm{N}_{2}$ tie points does not change the AICC2012 chronology, but mainly leads to an "unrealistically" small uncertainty (i.e. less than $2 \mathrm{ka}$ before $150 \mathrm{ka}$ for Vostok).

\subsubsection{Air content}

Air content measurements have been published for the Vostok ice core (150-400 ka, Lipenkov et al., 2011) and for the youngest part of the EDC ice core (0-440 ka, Raynaud et al., 2007) but no orbital tie points were provided. To build such tables, we have followed two different approaches, the one proposed by Raynaud et al. (2007) and the one similar to what has been applied for $\delta \mathrm{O}_{2} / \mathrm{N}_{2}$ and $\delta^{18} \mathrm{O}_{\mathrm{atm}}$.

The method used by Raynaud et al. (2007) and Lipenkov et al. (2011) is to calculate the time delay between air content, filtered in the $1 / 15$ and $1 / 46 \mathrm{ka}^{-1}$ pass-band, and the integrated local summer insolation (ISI). The ISI curve is obtained by summation of all daily summer insolation above a certain threshold; the threshold being inferred such that the ISI curve has the same spectral properties as the air content. From the cross-correlation between the two filtered signals, they have calculated a time delay, allowing us to associate ages calculated from orbital parameters to mid-slope variations of air content. Using this method, we have determined 14 and 8 orbital ice ages for EDC and Vostok ice cores respectively (Tables 4 and 5). In order to verify the robustness of these points, we also deduced ages by direct matching of the mid-slope variations of the unfiltered air content with the mid-slopes of the ISI target. Age markers obtained with these two methods are consistent within \pm 1 ka on average. The uncertainty for each point was calculated as a function of the sampling resolution, the uncertainty of the currently used chronology, the uncertainty of the ISI curves and the
Table 5. Orbital ages from air content for Vostok, deduced from Lipenkov et al. (2011).

\begin{tabular}{ccc}
\hline depth $(\mathrm{m})$ & ice age $(\mathrm{ka})$ & $\sigma(\mathrm{ka})$ \\
\hline 2420.28 & 191.950 & 6.663 \\
2488.27 & 202.950 & 6.600 \\
2848.45 & 260.950 & 7.215 \\
2883.02 & 275.950 & 6.343 \\
3011 & 307.950 & 6.424 \\
3043.04 & 318.950 & 6.308 \\
3145.95 & 346.950 & 6.527 \\
3185.46 & 359.950 & 6.704 \\
\hline
\end{tabular}

age difference with the direct mid-slope method, leading to values from 2.9 to $7.2 \mathrm{ka}$.

\subsection{Coherency of orbital markers for the Vostok ice core}

In order to evaluate the coherency of the 3 types of orbital markers, we have performed several "chronology tests" using the Datice tool with all the absolute and stratigraphic markers but only one type of orbital markers $\left(\delta^{18} \mathrm{O}_{\mathrm{atm}}, \delta \mathrm{O}_{2} / \mathrm{N}_{2}\right.$ or air content only). The full comparison between the " $\delta \mathrm{O}_{2} / \mathrm{N}_{2}$ chronology", " ${ }^{18} \mathrm{O}_{\mathrm{atm}}$ chronology" and the "air content chronology" can only be done when the different orbital marker ages overlap, hence on the Vostok ice core.

When comparing the $\delta \mathrm{O}_{2} / \mathrm{N}_{2}$ and air content chronologies (Fig. 4), the two chronologies seem in good agreement in the period 190-365 ka when markers overlap. The air content markers alone are leading to a chronology younger by $2 \mathrm{ka}$ maximum than the $\delta \mathrm{O}_{2} / \mathrm{N}_{2}$ one during this period. Prior to $365 \mathrm{ka}$, the comparison cannot be drawn since there is no air content constraint. This coherency of the two dating methods within $2 \mathrm{ka}$ during the period 190-365 ka confirms the conclusion of Lipenkov et al. (2011).

We concentrate now on the comparison of $\delta \mathrm{O}_{2} /$ $\mathrm{N}_{2}-\delta^{18} \mathrm{O}_{\text {atm }}$ chronologies in the $110-400$ ka period where $\delta \mathrm{O}_{2} / \mathrm{N}_{2}$ and $\delta^{18} \mathrm{O}_{\mathrm{atm}}$ age markers are homogeneously distributed. We observe differences varying from $\sim 2$ to $4 \mathrm{ka}$. These differences are slightly lower (standard deviation of $\pm 1.2 \mathrm{ka}$ and difference ranging from -0.005 to $4.1 \mathrm{ka}$ ) with Datice than in the similar comparison for Suwa and Bender (2008) (standard deviation of $\pm 1.9 \mathrm{ka}$ and a range of $\pm 6 \mathrm{ka}$ ). They may result from different links between gas and ice chronologies. In this study we consider the $\delta^{18} \mathrm{O}_{\mathrm{atm}}$ markers as gas age makers and the link between the gas and ice phases is governed by the LIDIE scenario based on $\delta^{15} \mathrm{~N}$ measurements and constraints from independent gas and ice stratigraphic links (SOM). In Suwa and Bender (2008), these markers were converted into ice ages and their gas age-ice age equivalence was obtained with a firnification model.

We do not explore in detail here the reasons for the systematic $2 \mathrm{ka}$ offset between the three chronologies. Many reasons can be involved, such as: 
- incorrect $\Delta$ age or LIDIE estimates, since the $\delta \mathrm{O}_{2} / \mathrm{N}_{2}$ and air content markers are ice age markers and the $\delta^{18} \mathrm{O}_{\text {atm }}$ is a gas age constraint;

- incorrect orbital targets for $\delta \mathrm{O}_{2} / \mathrm{N}_{2}$, air content and $\delta^{18} \mathrm{O}_{\text {atm }}$. In particular, no definitive quantitative explanation has been given for the $5 \mathrm{ka}$ lag between precession parameter and $\delta^{18} \mathrm{O}_{\text {atm }}$. Similarly, it is still under discussion if the $\delta \mathrm{O}_{2} / \mathrm{N}_{2}$ curve should be strictly aligned with the summer solstice insolation (Landais et al., 2012; Hutterli et al., 2010).

Moreover, for each orbital tuning, lags between the records and their orbital targets may vary with time (Jouzel et al., 2002).

We conclude that all orbitally tuned chronologies agree well one with each other. This permits us to safely combine the ice and gas orbital ages within their uncertainty range.

\section{New chronology}

\subsection{Chronology construction}

When combining all the different observations (absolute ages, stratigraphic links, $\Delta$ depth and orbital ages), 3 orbital markers have been removed because they led to anomalous peaks of LIDIE, which are not realistic ( $10 \mathrm{~m}$ variations within $12 \mathrm{ka}$ during MIS 12 and MIS 14, see SOM). The removed points are indicated by a "*” in Table 1: they are all gas age markers from $\delta^{18} \mathrm{O}_{\text {atm }}$ of the EDC ice core located near eccentricity minima (438 and $534 \mathrm{ka}$ ).

300 different Datice simulations were run to optimize the final AICC2012 chronology. In addition to tests of the coherency for the different absolute, orbital and stratigraphic points, it has been found that the background parameters and associated variances have a strong influence on the final chronologies. For example, we had to strongly enlarge the variance of the TALDICE thinning function. Indeed, the background chronology of TALDICE has a much too young Termination II (110 ka), which is unrealistic and should not influence the final AICC2012 chronology.

\subsection{The new AICC2012 chronology on orbital timescale}

As expected from the numerous stratigraphic markers distributed on the 5 ice cores, the variations imprinted in the methane and water isotopic composition are synchronous within $1.5 \mathrm{ka}$ for our five ice cores on the new AICC2012 chronology over the last $350 \mathrm{ka}$ (Fig. 5). Prior to $350 \mathrm{ka}$, there is no stratigraphic tie point between EDC and Vostok so that the AICC2012 chronologies are independently established for Vostok and EDC, using their individual $\delta^{18} \mathrm{O}_{\mathrm{atm}}, \delta \mathrm{O}_{2} / \mathrm{N}_{2}$ and air content markers indicated on Fig. 5. New measurements of $\mathrm{CH}_{4}$ and $\delta^{18} \mathrm{O}_{\text {atm }}$ are strongly needed to provide stratigraphic links between the two cores back to $400 \mathrm{ka}$.
Table 6. Comparison of the warm interglacial durations at EDC on the AICC2012 and EDC3 age scales.

\begin{tabular}{lcccc}
\hline Interglacial & \multicolumn{2}{c}{ EDC EDC3 $(\mathrm{ka})$} & \multicolumn{2}{c}{ EDC AICC2012 (ka) } \\
\hline MIS 1 & $0-12.0$ & $(12.0)$ & $0-12.3$ & $(12.3)$ \\
MIS 5.5 & $116.3-132.5$ & $(16.2)$ & $115.6-132.4$ & $(16.8)$ \\
MIS 7.5 & $239.8-244.7$ & $(4.9)$ & $240.8-245.8$ & $(5.0)$ \\
MIS 9.3 & $323.3-336.8$ & $(13.5)$ & $324.6-338.8$ & $(14.2)$ \\
MIS 11.3 & $395.3-426.1$ & $(30.8)$ & $395.5-426.6$ & $(31.1)$ \\
\hline
\end{tabular}

For the EDC ice core, the new AICC2012 chronology is in rather good agreement (within 2-3 ka) with the previous EDC3 timescale (Parrenin et al., 2007) as shown from the water isotope and $\mathrm{CH}_{4}$ records (Fig. 6). In particular, it does not modify significantly the length of interglacial periods (Table 6). Nevertheless, one period shows significant differences, up to $5.4 \mathrm{ka}$ (shaded zone on Fig. 6), corresponding to MIS 12. Termination V appears similar (within 390 a) in AICC2012 and EDC3, and MIS 11 duration is not significantly changed (Table 6). This period is close to the minimum of eccentricity characterizing MIS 11 , which makes the identification of orbital markers difficult by comparison of $\delta \mathrm{O}_{2} / \mathrm{N}_{2}$ and $\delta^{18} \mathrm{O}_{\mathrm{atm}}$ records with their respective tuning targets. In this study we have improved the resolution of EDC $\delta^{18} \mathrm{O}_{\text {atm }}$ over MIS $11-12$, leading to the determination of new orbital ages replacing those of Dreyfus et al. (2007), used to construct the EDC 3 chronology. Consequently, the differences observed over this period between the two chronologies mainly result from the replacement of the $\delta^{18} \mathrm{O}_{\text {atm }}$ age markers and the addition of ice age markers. Because the identification of orbital age markers remains difficult over this period of low eccentricity, new measurements of $\delta \mathrm{O}_{2} / \mathrm{N}_{2}$ and air content on the EDC ice core are still needed, especially for the small precession peaks at $350-450 \mathrm{ka}$. The new AICC2012 chronology has also been compared with absolute chronologies established for speleothems. For this purpose, variations of $\mathrm{CH}_{4}$ in the AICC2012 chronology are compared with variations of the $\delta^{18} \mathrm{O}$ of calcite in Chinese speleothems (Wang et al., 2008; Cheng et al., 2009) assuming that both should vary in phase. A strong resemblance and synchronism have indeed been observed between calcite $\delta^{18} \mathrm{O}$ and $\mathrm{CH}_{4}$ variability over Dansgaard-Oeschger events (Fleitmann et al., 2009). The AICC2012 chronology appears in good agreement, within its uncertainty, with the speleothem ages over the considered events (see Table 6 in SOM).

The dating improvements for the AICC2012 chronology concern mainly the last $150 \mathrm{ka}$, where the numerous new stratigraphic links permit to significantly decrease the dating uncertainties. In the companion paper, Veres et al. (2013) discuss the millennial scale variability of the last $120 \mathrm{ka}$ and we focus here on MIS 5.5. The records are coherent over this period between the 4 Antarctic ice cores (Fig. 7), within 
a

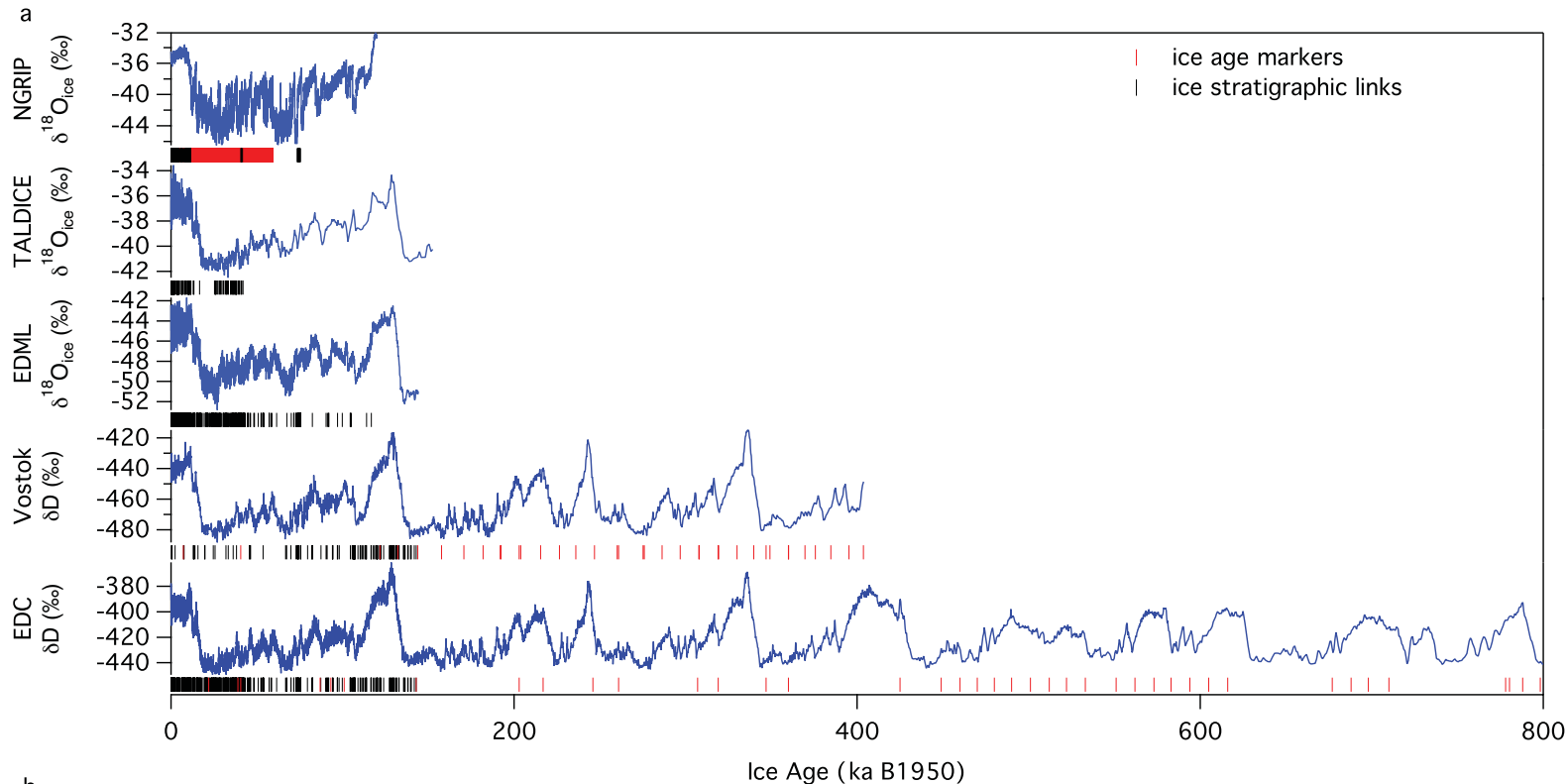

b

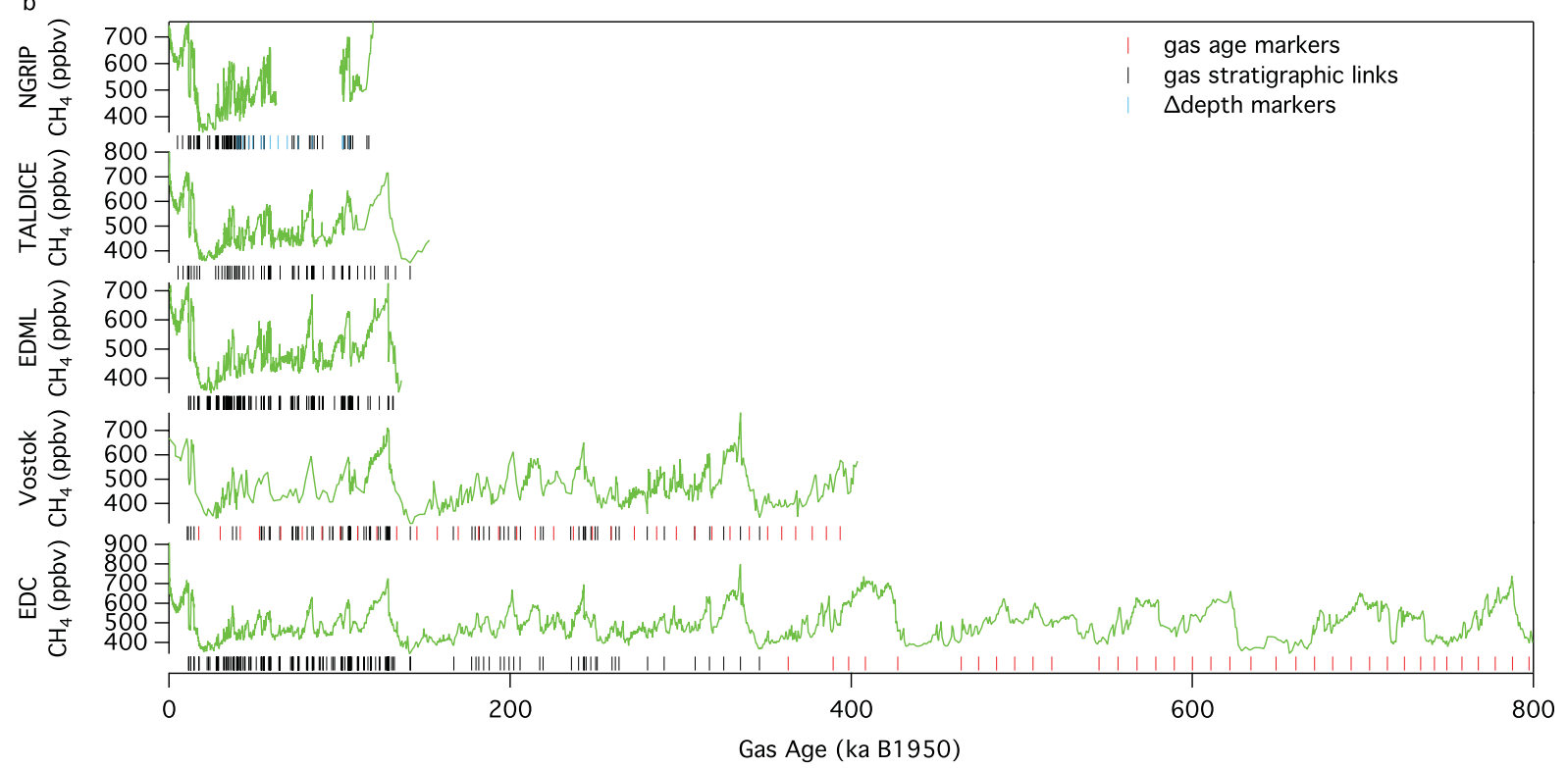

Fig. 5. (a) Water stable isotope records of NGRIP (NorthGRIP Community Members, 2004), TALDICE (Stenni et al., 2011), EDML (EPICA Community Members, 2006, 2010), Vostok (Petit et al., 1999) and EDC (Jouzel et al., 2007) on the AICC2012 age scale. (b) Methane records of NGRIP (Greenland composite: Capron et al., 2010; EPICA Community Members, 2006; Flückiger et al., 2004; Huber et al., 2006; Schilt et al., 2010), TALDICE (Buiron et al., 2011; Schüpbach et al., 2011), EDML (EPICA Community Members, 2006), Vostok (Caillon et al., 2003; Delmotte et al., 2004; Petit et al., 1999) and EDC (Loulergue et al., 2008) on the AICC2012 age scale. Stratigraphic links and age marker positions are displayed under each core.

the uncertainty of AICC2012, with the Vostok ice core being slightly older $(1 \mathrm{ka})$ than the other ice cores. The duration of MIS 5.5, defined here by the $-403 \%$ o threshold of $\delta \mathrm{D}$ on EDC (EPICA Community Members, 2004), is slightly longer in AICC2012 (16.8 ka) compared to its duration in the EDC3 chronology $(16.2 \mathrm{ka})$ and the age of Termination II is not significantly modified compared to its age in EDC3. Still, the reduction of uncertainty associated with the age of Termination II and MIS 5.5 compared to previous ice core chronologies makes it interesting to compare our result with other dated records.

Absolute dating of Termination II has been possible in at least two well-dated speleothems. In China, Cheng et al. (2009) dated a strong decrease of calcite $\delta^{18} \mathrm{O}$ in the Sanbao cave speleothem at $128.91 \pm 0.06 \mathrm{ka}$. In Italy, Drysdale et al. (2009) obtained a decrease in calcite $\delta^{18} \mathrm{O}$ on a speleothem of the Corchia cave in two steps: a first $1.5 \%$ o decrease between 133 and $131 \mathrm{ka}$ and a second decrease of $1 \%$ o between 129 


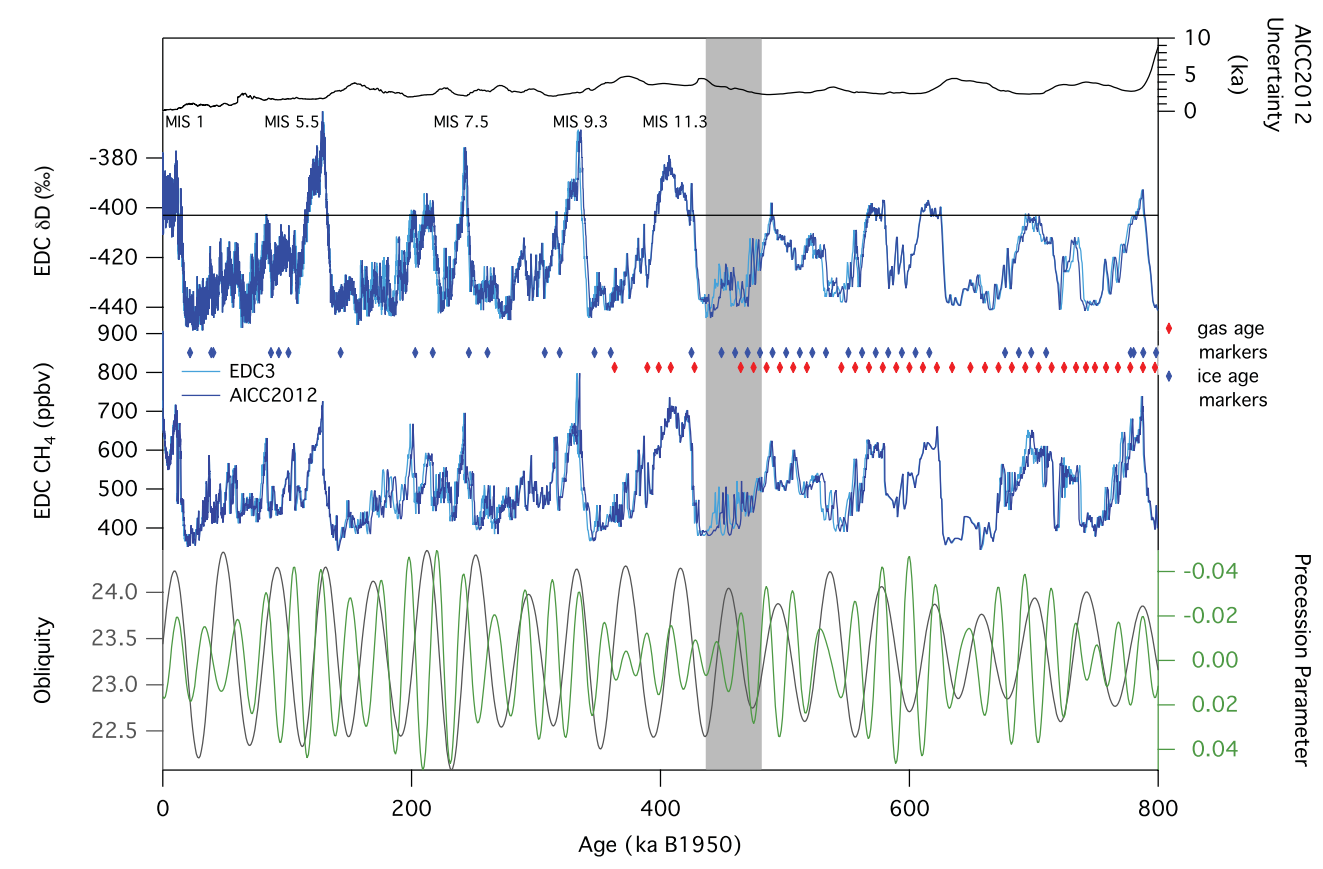

Fig. 6. Top: EDC AICC2012 chronology uncertainty. EDC deuterium records (EPICA Community Members, 2004) over the last 800 ka on the EDC3 (light blue) and AICC2012 (dark blue) age scales. The horizontal line corresponds to $-403 \%$ and limits the interglacial periods (EPICA Community Members, 2004). The position of the orbital markers is shown in the gas (red markers) and ice (blue markers). Middle: $\mathrm{CH}_{4}$ records of EDC (Loulergue et al., 2008) on EDC3 (light blue) and AICC2012 (dark blue). Bottom: obliquity (grey) and precession parameter (green) over the last $800 \mathrm{ka}$ (same as in Fig. 1). The shaded zone highlights the period of significant differences between the two chronologies.

and $128 \mathrm{ka}$. There is a priori no contradiction between these two dates since calcite $\delta^{18} \mathrm{O}$ reflects local or regional intensity of the hydrological cycle in China while the impact of local temperature on meteoric water and then calcite $\delta^{18} \mathrm{O}$ is expected to be more pronounced in Italy. The different dates for the calcite $\delta^{18} \mathrm{O}$ decrease may thus reflect different regional climatic response during Termination II.

Termination II is well recorded in Antarctic ice cores. At EDC, the main features are: (1) a parallel slow increase of both $\delta \mathrm{D}$ and $\mathrm{CO}_{2}$ from 135 to $128 \mathrm{ka}$, (2) an abrupt shift of methane and d-excess occurring during the optimum of $\delta \mathrm{D}$ and $\mathrm{CO}_{2}$ (Lourantou et al., 2010; Masson-Delmotte et al., 2010a). In the EDC3 timescale, Termination II was constrained with a speleothem-deduced age of $130.1 \pm 2.0 \mathrm{ka}$ (Parrenin et al., 2007) synchronized with the methane peak of EDC and converted as an ice depth with an estimated $\Delta$ depth. This does not permit to compare independently the ice and speleothem records. As a consequence, in our new chronology, we have removed this tie point from the list of absolute markers and we only use orbital markers $\left(\delta \mathrm{O}_{2} / \mathrm{N}_{2}\right.$, air content and $\left.\delta^{18} \mathrm{O}_{\mathrm{atm}}\right)$. Tests performed with the Datice tool with or without the $130.1 \mathrm{ka}$ tie point using the published or an enlarged uncertainty do not change by more than a few centuries the timing of the abrupt increase of $\mathrm{CH}_{4}$ or maximum of $\delta \mathrm{D}$ observed at $128.51 \mathrm{ka}$ on the EDC AICC2012 timescale (128.79 ka for Vostok)

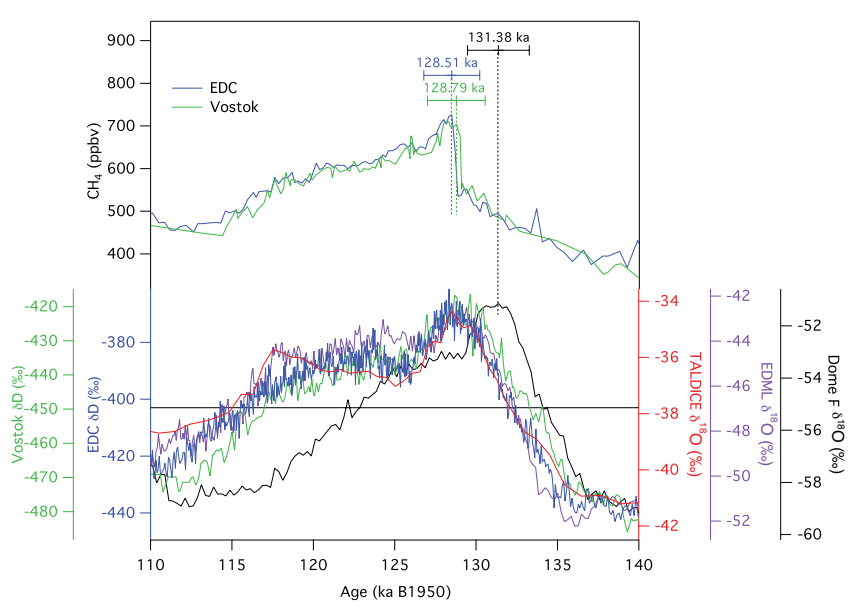

Fig. 7. Bottom: comparison of MIS 5.5 duration in several ice cores. The EDC, Vostok, EDML and TALDICE isotopic records are on AICC2012 age scales. The Dome $\mathrm{F} \delta^{18} \mathrm{O}$ is on the DFO2006 chronology (Kawamura et al., 2007). The black horizontal line corresponds to the $-403 \%$ interglacial threshold on EDC. Top: methane records of Vostok and EDC. Termination II ages are defined from the timing of the sharp methane rise for EDC (blue) and Vostok (green), and the water stable isotope optima for Dome F (black). 
compared to $128.66 \mathrm{ka}$ on the EDC3 timescale (Fig. 7). This result supports the hypothesis of synchronism between $\mathrm{CH}_{4}$ abrupt increases recorded in ice cores and abrupt calcite $\delta^{18} \mathrm{O}$ recorded in East Asiatic caves. However, it should be noted that this is only valid within the uncertainty of our timescale ( $1.72 \mathrm{ka}$ given by Datice at Termination II, see SOM). We conclude that our AICC2012 chronology appears consistent with the speleothem information.

Even if this dating of Termination II with AICC2012 agrees, within the uncertainties, with the Termination II dating at Dome F, the AICC2012 chronology is $3 \mathrm{ka}$ younger than the DFO-2006 chronology placing the $\delta$ D optimum at $131.38 \pm 1.90 \mathrm{ka}$ (Kawamura et al., 2007). This difference may have different origins. Most importantly, the quality of the $\delta \mathrm{O}_{2} / \mathrm{N}_{2}$ measurements on which both AICC2012 and Dome $\mathrm{F}$ chronologies are based is limited by gas loss issues on ice kept at $-20^{\circ} \mathrm{C}$. Moreover the $\delta^{18} \mathrm{O}_{\text {atm }}$ variability is at a minimum before the onset of Termination II, making a unique orbital tuning very difficult at that time. New measurements on well-conserved ice should be performed to improve the records.

Finally, the AICC2012 chronology suggests synchronous millennial variations of water stable isotopes at EDC, EDML, and Vostok during the last interglacial, supporting earlier hypotheses (Masson-Delmotte et al., 2011). It also highlights a sharp cooling at $117 \mathrm{ka}$ synchronous in EDML and TALDICE, and distinct from the other more inland records. This behavior is inferred from the stratigraphic links between the Antarctic ice cores and also the $\delta^{18} \mathrm{O}_{\text {atm }}$ markers of TALDICE around this period. It confirms the different isotope trend at TALDICE and EDC during the last interglacial period, supporting interpretations of this gradient as a glaciological fingerprint of changes in East Antarctic ice sheet topography (Bradley et al., 2013).

\section{Conclusions}

In this study, together with the companion study of Veres et al. (2013), we have established a new reference chronology for 4 Antarctic ice cores, AICC2012 covering the last $800 \mathrm{ka}$. An important aspect of the common chronology development has been the compilation of absolute and stratigraphic tie points as well as a careful evaluation of the background scenarios and associated variances for thinning, accumulation rate and LIDIE. These results are available in the Supplement associated with the AICC2012 chronology.

More specifically, we have focused here on the orbital timescale between 120 and $800 \mathrm{ka}$. First, we have presented new measurements of $\delta^{18} \mathrm{O}_{\text {atm }}$ of EDC over MIS 11-12 to improve the determination of orbital markers over this period characterized by a low eccentricity. Second, we have provided a complete record of $\delta^{18} \mathrm{O}_{\mathrm{atm}}$ for the TALDICE ice core prior to $50 \mathrm{ka}$. This new record has permitted to provide 8 new stratigraphic links with Vostok over the last
$150 \mathrm{ka}$. With this new record, we have also pointed out that the integrity of the TALDICE ice core prior to $150 \mathrm{ka}$ is questionable. Third, we have tested the coherency of the different orbital ages derived from air content, $\delta \mathrm{O}_{2} / \mathrm{N}_{2}$ and $\delta^{18} \mathrm{O}_{\text {atm }}$ and have concluded that the three markers are coherent at Vostok between 190 and $365 \mathrm{ka}$, within their respective uncertainties.

The methane and water isotopic records from the 4 Antarctic ice cores are coherent when drawn on the new AICC2012 chronology, supporting earlier interpretations. Small differences between EDC isotopic records drawn on AICC2012 and on the previous EDC3 chronology are evident. Most of the age scale differences between 110 and $800 \mathrm{ka}$ are smaller than $1.5 \mathrm{ka}$, hence not significant given the uncertainty of AICC2012. The main conclusions on the orbital properties of methane and water stable isotope variations, and their lags with respect to orbital forcing (Jouzel et al., 2007; Loulergue et al., 2008; Masson-Delmotte et al., 2010b) remain robust. Only over MIS 12, the two chronologies differ by up to $5.4 \mathrm{ka}$, due to our new measurements of $\delta^{18} \mathrm{O}_{\mathrm{atm}}$ and the addition of new age markers. The timing and duration of MIS 5 in AICC2012 is basically unchanged compared to EDC3. This is an important result since the dating of Termination II in AICC2012 does not rely anymore on the speleothem derived tie point at $130.1 \mathrm{ka}$ which was included in EDC3. It mainly results from ice core orbital markers and numerous new stratigraphic links, with still an influence of the background scenarios.

We have also pointed out the necessity of new measurements. First, higher sampling resolution for ice $\delta^{18} \mathrm{O}$, methane and $\delta^{18} \mathrm{O}_{\text {atm }}$ over the TALDICE ice core are needed prior to $150 \mathrm{ka}$ to assess the integrity of this ice core over its bottom part. Second, new measurements of $\delta \mathrm{O}_{2} / \mathrm{N}_{2}$, air content and $\delta^{18} \mathrm{O}_{\mathrm{atm}}$ of the EDC ice core on well-conserved ice are strongly required in order to fill the gap of orbital markers over the following periods: $440-800 \mathrm{ka}$ for air content, $0-400 \mathrm{ka}$ for $\delta^{18} \mathrm{O}_{\mathrm{atm}}, 0-380$ and $480-700 \mathrm{ka}$ for $\delta \mathrm{O}_{2} / \mathrm{N}_{2}$. Third, methodological aspects of the Datice tool also need improvements on the choice of background parameters and associated variances. As an example, new insights of the LID controls should be included in Datice (Freitag et al., 2012; Capron et al., 2013). Information from microstructure and fabric should help to better define the thinning function variance (Durand et al., 2007). Finally, an important added value would be to further extend the Datice tool to include other ice cores such as Dome F, WAIS or also the NEEM ice core in Greenland, all of these ice cores being highly documented with absolute or orbital markers.

\section{Supplementary material related to this article is available online at: http://www.clim-past.net/9/1715/ 2013/cp-9-1715-2013-supplement.zip.}


Acknowledgements. We thank Jeff Severinghaus and the 3 anonymous reviewers for their comments permitting us to improve the clarity of this paper. We thank the EDC4 team for stimulating the discussion around the building of AICC2012 and helping to pick up the best parameters to feed the Datice tool. We address special thanks to Sébastien Nomade and Frédéric Prié for their help in this study. This project was funded by the "Fondation de France Ars Cuttoli", the "ANR Citronnier", INRIA and LEFE funding. The research leading to these results has received funding from the European Union's Seventh Framework programme (FP7/2007-2013) under grant agreement no 243908, "Past4Future. Climate change - Learning from the past climate". This work is a contribution to the European Project for Ice Coring in Antarctica (EPICA), a joint European Science Foundation/European Commission scientific programme, funded by the EU and by national contributions from Belgium, Denmark, France, Germany, Italy, the Netherlands, Norway, Sweden, Switzerland and the United Kingdom. The main logistic support was provided by IPEV and PNRA (at Dome C) and AWI (at Dronning Maud Land). The Talos Dome Ice core Project (TALDICE), a joint European programme, is funded by national contributions from Italy, France, Germany, Switzerland and the United Kingdom. Primary logistical support was provided by PNRA at Talos Dome. This is EPICA publication no. 292. This is Past4Future contribution number 46. This is TALDICE publication no 34. This is LSCE contribution no 4646.

Edited by: E. Brook

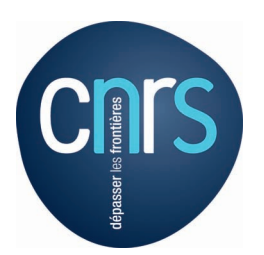

The publication of this article is financed by CNRS-INSU.

\section{References}

Aciego, S., Bourdon, B., Schwander, J., Baur, H., and Forieri, A.: Toward a radiometric ice clock: uranium ages of the Dome C ice core, Quaternary Sci. Rev., 30, 2389-2397, doi:10.1016/j.quascirev.2011.06.008, 2011.

Arnaud, L., Barnola, J.-M., and Duval, P.: Physical modeling of the densification of snow/firn and ice in the upper part of polar ice sheets, Book: Physics of Ice Core Records, 285-305, edited by: Hondoh, T., Hokkaido Univ. Press, Sapporo, Japan, 2000

Bar-Matthews, M., Ayalon, A., Gilmour, M., Matthews, A., and Hawkesworth, C. J.: Sea-land oxygen isotopic relationships from planktonic foraminifera and speleothems in the Eastern Mediterranean region and their implication for paleorainfall during interglacial intervals, Geochim. Cosmochim. Ac., 67, 3181-3199, doi:10.1016/S0016-7037(02)01031-1, 2003.

Battle, M., Bender, M., Sowers, T., Tans, P. P., Butler, J. H., Elkins, J. W., Ellis, J. T., Conway, T., Zhang, N., Lang, P., and Clarket, A. D.: Atmospheric gas concentrations over the past century measured in air from firn at the South Pole, Nature, 383, 231-235, doi:10.1038/383231a0, 1996.
Bender, M. L.: Orbital tuning chronology for the Vostok climate record supported by trapped gas composition, Earth Planet. Sci. Lett., 204, 275-289, doi:10.1016/S0012-821X(02)00980-9, 2002.

Bender, M., Sowers, T., and Labeyrie, L.: The Dole effect and its variations during the last 130000 years as measured in the Vostok ice core, Global Biogeochem. Cy., 8, 363-376, doi:10.1029/94GB00724, 1994.

Bradley, S. L., Siddall, M., Milne, G. A., Masson-Delmotte, V., and Wolff, E.: Combining ice core records and ice sheet models to explore the evolution of the East Antarctic Ice sheet during the Last Interglacial period, Global Planet. Change, 100278-100290, doi:10.1016/j.gloplacha.2012.11.002, 2013.

Buiron, D., Chappellaz, J., Stenni, B., Frezzotti, M., Baumgartner, M., Capron, E., Landais, A., Lemieux-Dudon, B., MassonDelmotte, V., Montagnat, M., Parrenin, F., and Schilt, A.: TALDICE-1 age scale of the Talos Dome deep ice core, East Antarctica, Clim. Past, 7, 1-16, doi:10.5194/cp-7-1-2011, 2011.

Caillon, N., Severinghaus, J. P., Jouzel, J., Barnola, J.-M., Kang, J., and Lipenkov, V. Y.: Timing of atmospheric $\mathrm{CO}_{2}$ and Antarctic temperature changes across termination III, Science, 299, 17281731, doi:10.1126/science.1078758, 2003.

Capron, E., Landais, A., Lemieux-Dudon, B., Schilt, A., MassonDelmotte, V., Buiron, D., Chappellaz, J., Dahl-Jensen, D., Johnsen, S., Leuenberger, M., Loulergue, L., and Oerter, H.: Synchronising EDML and NorthGRIP ice cores using $\delta^{18} \mathrm{O}$ of atmospheric oxygen $\left(\delta^{18} \mathrm{O}_{\mathrm{atm}}\right)$ and $\mathrm{CH}_{4}$ measurements over MIS5 (80-123 kyr), Quaternary Sci. Rev., 29, 222-234, doi:10.1016/j.quascirev.2009.07.014, 2010.

Capron, E., Landais, A., Buiron, D., Cauquoin, A., Chappellaz, J., Debret, M., Jouzel, J., Leuenberger, M., Martinerie, P., MassonDelmotte, V., Mulvaney, R., Parrenin, F., and Prié, F.: Glacialinterglacial dynamics of Antarctic firns: comparison between simulations and ice core air-d15N measurements, Clim. Past, 9, 983-999, doi:http://dx.doi.org/10.5194/cp-9-983-2013, 2013.

Cheng, H., Edwards, R. L., Broecker, W. S., Denton, G. H., Kong, X., Wang, Y., Zhang, R., and Wang, X.: Ice Age terminations, Science, 326, 248-252, doi:10.1126/science.1177840, 2009.

Delmotte, M., Chappellaz, J., Brook, E., Yiou, P., Barnola, J. M., Goujon, C., Raynaud, D., and Lipenkov, V. I.: Atmospheric methane during the last four glacial-interglacial cycles: rapid changes and their link with Antarctic temperature, J. Geophys. Res.-Atmos, 109, D12104, doi:10.1029/2003JD004417, 2004.

Dreyfus, G. B., Parrenin, F., Lemieux-Dudon, B., Durand, G., Masson-Delmotte, V., Jouzel, J., Barnola, J.-M., Panno, L., Spahni, R., Tisserand, A., Siegenthaler, U., and Leuenberger, M.: Anomalous flow below $2700 \mathrm{~m}$ in the EPICA Dome $\mathrm{C}$ ice core detected using $\delta^{18} \mathrm{O}$ of atmospheric oxygen measurements, Clim. Past, 3, 341-353, doi:10.5194/cp-3-341-2007, 2007.

Dreyfus, G. B., Raisbeck, G. M., Parrenin, F., Jouzel, J., Guyodo, Y., Nomade, S., and Mazaud, A.: An ice core perspective on the age of the Matuyama-Brunhes boundary, Earth Planet. Sci. Lett., 274, 151-156, doi:10.1016/j.epsl.2008.07.008, 2008.

Drysdale, R. N., Hellstrom, J. C., Zanchetta, G., Fallick, A. E., Sanchez Goñi, M. F., Couchoud, I., McDonald, J., Maas, R., Lohmann, G., and Isola, I.: Evidence for obliquity forcing of glacial termination II, Science, 325, 1527-1531, doi:10.1126/science.1170371, 2009. 
Dunbar, N. W., McIntosh, W. C., and Esser, R. P.: Physical setting and tephrochronology of the summit caldera ice record at Mount Moulton, West Antarctica, Geol. Soc. Am. Bull., 120, 796-812, doi:10.1130/B26140.1, 2008

Durand, G., Gillet-Chaulet, F., Svensson, A., Gagliardini, O., Kipfstuhl, S., Meyssonnier, J., Parrenin, F., Duval, P., and Dahl-Jensen, D.: Change in ice rheology during climate variations - implications for ice flow modelling and dating of the EPICA Dome C core, Clim. Past, 3, 155-167, doi:10.5194/cp-3-155-2007, 2007.

EPICA Community Members: Eight glacial cycles from an Antarctic ice core, Nature, 429, 623-628, doi:10.1038/nature02599, 2004.

EPICA Community Members: One-to-one coupling of glacial climate variability in Greenland and Antarctica, Nature, 444, 195198, doi:10.1038/nature05301, 2006.

EPICA Community Members: Stable oxygen isotopes of ice core EDML, PANGAEA, doi:10.1594/PANGAEA.754444, 2010.

Fleitmann, D., Cheng, H., Badertscher, S., Edwards, R. L., Mudelsee, M., Göktürk, O. M., Fankhauser, A., Pickering, R., Raible, C. C., Matter, A., Kramers, J., and Tüysüz, O.: Timing and climatic impact of Greenland interstadials recorded in stalagmites from Northern Turkey, Geophys. Res. Lett., 36, L19707, doi:10.1029/2009GL040050, 2009.

Flückiger, J., Blunier, T., Stauffer, B., Chappellaz, J., Spahni, R., Kawamura, K., Schwander, J., Stocker, T. F., and DahlJensen, D.: $\mathrm{N}_{2} \mathrm{O}$ and $\mathrm{CH}_{4}$ variations during the last glacial epoch: Insight into global processes, Global Biogeochem. Cy., 18, GB1020, doi:10.1029/2003GB002122, 2004.

Freitag, J., Kipfstuhl, S., Hörhold, M., Wegner, A., Wilhelms, F., and Bigler, M.: Impurity controlled firn densification: a new model approach, in: EGU General Assembly Conference Abstracts, edited by: Abbasi, A. and Giesen, N., vol. 14 of EGU General Assembly Conference Abstracts, 10293, Vienna, Austria, 22-27 April 2012, 2012.

Gilbert, J. and Lemarechal, C.: The modules M1QN3 and N1QN3, Program documentation, INRIA, 1993.

Goujon, C., Barnola, J.-M., and Ritz, C.: Modeling the densification of polar firn including heat diffusion: application to closeoff characteristics and gas isotopic fractionation for Antarctica and Greenland sites, J. Geophys. Res.-Atmos., 108, 4792, doi:10.1029/2002JD003319, 2003.

Herron, M. M. and Langway Jr., C. C.: Firn densification: an empirical model, J. Glaciol., 25, 373-385, 1980.

Hoffmann, G., Cuntz, M., Weber, C., Ciais, P., Friedlingstein, P., Heimann, M., Jouzel, J., Kaduk, J., Maier-Reimer, E., Seibt, U., and Six, K.: A model of the Earth's Dole effect, Global Biogeochem. Cy., 18, GB1008, doi:10.1029/2003GB002059, 2004.

Huber, C., Beyerle, U., Leuenberger, M., Schwander, J., Kipfer, R., Spahni, R., Severinghaus, J. P., and Weiler, K.: Evidence for molecular size dependent gas fractionation in firn air derived from noble gases, oxygen, and nitrogen measurements, Earth Planet. Sci. Lett., 243, 61-73, doi:10.1016/j.eps1.2005.12.036, 2006.

Hutterli, M. A., Schneebeli, M., Freitag, J., Kipfstuhl, J., and Rothlisberger, R.: Impact of local insolation on snow metamorphism and ice core records, in: Physics of Ice Core Records II, edited by: Hondoh, T., Hokkaido University Press, 223-232, Sapporo, Japan, 2010.
Imbrie, J. and Imbrie, J. Z.: Modeling the climatic response to orbital variations, Science, 207, 943-953, doi:10.1126/science.207.4434.943, 1980.

Jouzel, J., Hoffmann, G., Parrenin, F., and Waelbroeck, C.: Atmospheric oxygen 18 and sea-level changes, Quaternary Sci. Rev., 21, 307-314, doi:10.1016/S0277-3791(01)00106-8, 2002.

Jouzel, J., Masson-Delmotte, V., Cattani, O., Dreyfus, G., Falourd, S., Hoffmann, G., Minster, B., Nouet, J., Barnola, J. M., Chappellaz, J., Fischer, H., Gallet, J. C., Johnsen, S., Leuenberger, M., Loulergue, L., Luethi, D., Oerter, H., Parrenin, F., Raisbeck, G., Raynaud, D., Schilt, A., Schwander, J., Selmo, E., Souchez, R., Spahni, R., Stauffer, B., Steffensen, J. P., Stenni, B., Stocker, T. F., Tison, J. L., Werner, M., and Wolff, E. W.: Orbital and millennial Antarctic climate variability over the past 800000 Years, Science, 317, 793-796, doi:10.1126/science.1141038, 2007.

Kawamura, K., Parrenin, F., Lisiecki, L., Uemura, R., Vimeux, F., Severinghaus, J. P., Hutterli, M. A., Nakazawa, T., Aoki, S., Jouzel, J., Raymo, M. E., Matsumoto, K., Nakata, H., Motoyama, H., Fujita, S., Goto-Azuma, K., Fujii, Y., and Watanabe, O.: Northern Hemisphere forcing of climatic cycles in Antarctica over the past 360000 years, Nature, 448, 912-916, doi:10.1038/nature06015, 2007.

Landais, A., Caillon, N., Severinghaus, J., Jouzel, J., and MassonDelmotte, V.: Analyses isotopiques à haute précision de l'air piégé dans les glaces polaires pour la quantification des variations rapides de température: méthodes et limites, Notes des activités instrumentales de l'IPSL, Technical Report, 39, 2003a.

Landais, A., Chappellaz, J., Delmotte, M., Jouzel, J., Blunier, T., Bourg, C., Caillon, N., Cherrier, S., Malaizé, B., MassonDelmotte, V., Raynaud, D., Schwander, J., and Steffensen, J. P.: A tentative reconstruction of the last interglacial and glacial inception in Greenland based on new gas measurements in the Greenland Ice Core Project (GRIP) ice core, J. Geophys. Res.-Atmos., 108, 4563, doi:10.1029/2002JD003147, 2003 b.

Landais, A., Barnola, J. M., Masson-Delmotte, V., Jouzel, J., Chappellaz, J., Caillon, N., Huber, C., Leuenberger, M., and Johnsen, S. J.: A continuous record of temperature evolution over a sequence of Dansgaard-Oeschger events during Marine Isotopic Stage 4 (76 to 62 kyr BP), Geophys. Res. Lett., 31, L22211, doi:10.1029/2004GL021193, 2004.

Landais, A., Jouzel, J., Massondelmotte, V., and Caillon, N.: Large temperature variations over rapid climatic events in Greenland: a method based on air isotopic measurements, C. R. Geosci., 337, 947-956, doi:10.1016/j.crte.2005.04.003, 2005.

Landais, A., Waelbroeck, C., and Masson-Delmotte, V.: On the limits of Antarctic and marine climate records synchronization: lag estimates during marine isotopic stages $5 \mathrm{~d}$ and 5c, Paleoceanography, 21, PA1001, doi::10.1029/2005PA001171, 2006.

Landais, A., Masson-Delmotte, V., Combourieu Nebout, N., Jouzel, J., Blunier, T., Leuenberger, M., Dahl-Jensen, D., and Johnsen, S.: Millenial scale variations of the isotopic composition of atmospheric oxygen over Marine Isotopic Stage 4, Earth Planet. Sci. Lett., 258, 101-113, doi::10.1016/j.epsl.2007.03.027, 2007.

Landais, A., Dreyfus, G., Capron, E., Masson-Delmotte, V., Sanchez-Goñi, M., Desprat, S., Hoffmann, G., Jouzel, J., Leuenberger, M., and Johnsen, S.: What drives the millennial and orbital variations of $\delta^{18} \mathrm{O}_{\mathrm{atm}}$ ?, Quaternary Sci. Rev., 29, 235-246, 
doi:10.1016/j.quascirev.2009.07.005, 2010.

Landais, A., Dreyfus, G., Capron, E., Pol, K., Loutre, M. F., Raynaud, D., Lipenkov, V. Y., Arnaud, L., Masson-Delmotte, V., Paillard, D., Jouzel, J., and Leuenberger, M.: Towards orbital dating of the EPICA Dome $\mathrm{C}$ ice core using $\delta \mathrm{O}_{2} / \mathrm{N}_{2}$, Clim. Past, 8, 191-203, doi:10.5194/cp-8-191-2012, 2012.

Laskar, J., Robutel, P., Joutel, F., Gastineau, M., Correia, A. C. M., and Levrard, B.: A long-term numerical solution for the insolation quantities of the Earth, Astron. Astrophys., 428, 261-285, doi:10.1051/0004-6361:20041335, 2004.

Lemieux-Dudon, B., Blayo, E., Petit, J.-R., Waelbroeck, C., Svensson, A., Ritz, C., Barnola, J.-M., Narcisi, B. M., and Parrenin, F.: Consistent dating for Antarctic and Greenland ice cores, Quat. Sci. Rev., 29, 8-20, doi:10.1016/j.quascirev.2009.11.010, 2010.

Leuenberger, M. C.: Modeling the signal transfer of seawater $\delta^{18} \mathrm{O}$ to the $\delta^{18} \mathrm{O}$ of atmospheric oxygen using a diagnostic box model for the terrestrial and marine biosphere, J. Geophys. Res., 102, 26841-26850, doi:10.1029/97JC00160, 1997.

Lipenkov, V. Y., Raynaud, D., Loutre, M. F., and Duval, P.: On the potential of coupling air content and $\mathrm{O}_{2} / \mathrm{N}_{2}$ from trapped air for establishing an ice core chronology tuned on local insolation, Quaternary Sci. Rev., 30, 3280-3289, doi:10.1016/j.quascirev.2011.07.013, 2011.

Lorius, C., Ritz, C., Jouzel, J., Merlivat, L., and Barkov, N. I.: A 150000-year climatic record from Antarctic ice, Nature, 316, 591-596, doi:10.1038/316591a0, 1985.

Loulergue, L.: Contraintes chronologiques et biogeochimiques grace au methane dans la glace naturelle: une application aux forages du projet EPICA, 2007, Ph. D. thesis, UJF, France, 2007.

Loulergue, L., Parrenin, F., Blunier, T., Barnola, J.-M., Spahni, R., Schilt, A., Raisbeck, G., and Chappellaz, J.: New constraints on the gas age-ice age difference along the EPICA ice cores, 0-50 kyr, Clim. Past, 3, 527-540, doi:10.5194/cp-3-527-2007, 2007.

Loulergue, L., Schilt, A., Spahni, R., Masson-Delmotte, V., Blunier, T., Lemieux, B., Barnola, J.-M., Raynaud, D., Stocker, T. F., and Chappellaz, J.: Orbital and millennial-scale features of atmospheric $\mathrm{CH}_{4}$ over the past 800000 years, Nature, 453, 383-386, doi:10.1038/nature06950, 2008.

Lourantou, A., Chappellaz, J., Barnola, J.-M., MassonDelmotte, V., and Raynaud, D.: Changes in atmospheric $\mathrm{CO}_{2}$ and its carbon isotopic ratio during the penultimate deglaciation, Quaternary Sci. Rev., 29, 1983-1992, doi:10.1016/j.quascirev.2010.05.002, 2010.

Lüthi, D., Le Floch, M., Bereiter, B., Blunier, T., Barnola, J.-M., Siegenthaler, U., Raynaud, D., Jouzel, J., Fischer, H., Kawamura, K., and Stocker, T. F.: High-resolution carbon dioxide concentration record 650000-800 000 years before present, Nature, 453, 379-382, doi:10.1038/nature06949, 2008.

Malaizé, B., Paillard, D., Jouzel, J., and Raynaud, D.: The Dole effect over the last two glacial-interglacial cycles, J. Geophys. Res., 104, 14199-14208, doi:10.1029/1999JD900116, 1999.

Masson-Delmotte, V., Stenni, B., Blunier, T., Cattani, O., Chappellaz, J., Cheng, H., Dreyfus, G., Edwards, R. L., Falourd, S., Govin, A., Kawamura, K., Johnsen, S. J., Jouzel, J., Landais, A., Lemieux-Dudon, B., Lourantou, A., Marshall, G., Minster, B., Mudelsee, M., Pol, K., Rothlisberger, R., Selmo, E., and Waelbroeck, C.: Abrupt change of Antarctic moisture origin at the end of Termination II, P. Natl. Acad. Sci. USA, 107, 12091-12094, doi:10.1073/pnas.0914536107, 2010a.

Masson-Delmotte, V., Stenni, B., Pol, K., Braconnot, P., Cattani, O., Falourd, S., Kageyama, M., Jouzel, J., Landais, A., Minster, B., Barnola, J. M., Chappellaz, J., Krinner, G., Johnsen, S., Röthlisberger, R., Hansen, J., Mikolajewicz, U., and Otto-Bliesner, B.: EPICA Dome $\mathrm{C}$ record of glacial and interglacial intensities, Quat. Sci. Rev., 29, 113-128, doi:10.1016/j.quascirev.2009.09.030, 2010b.

Masson-Delmotte, V., Buiron, D., Ekaykin, A., Frezzotti, M., Gallée, H., Jouzel, J., Krinner, G., Landais, A., Motoyama, H., Oerter, H., Pol, K., Pollard, D., Ritz, C., Schlosser, E., Sime, L. C., Sodemann, H., Stenni, B., Uemura, R., and Vimeux, F.: A comparison of the present and last interglacial periods in six Antarctic ice cores, Clim. Past, 7, 397-423, doi:10.5194/cp-7-397-2011, 2011.

NorthGRIP Community Members: High-resolution record of Northern Hemisphere climate extending into the last interglacial period, Nature, 431, 147-151, doi:10.1038/nature02805, 2004.

Paillard, D., Labeyrie, L., and Yiou, P.: Macintosh Program performs time-series analysis, EOS Transactions, 77, 379-379, doi:10.1029/96EO00259, 1996.

Parrenin, F., Jouzel, J., Waelbroeck, C., Ritz, C., and Barnola, J.-M.: Dating the Vostok ice core by an inverse method, J. Geophys. Res., 106, 31837-31852, doi:10.1029/2001JD900245, 2001.

Parrenin, F., Rémy, F., Ritz, C., Siegert, M. J., and Jouzel, J.: New modeling of the Vostok ice flow line and implication for the glaciological chronology of the Vostok ice core, J. Geophys. Res.-Atmos., 109, D20102, doi:10.1029/2004JD004561, 2004.

Parrenin, F., Barnola, J.-M., Beer, J., Blunier, T., Castellano, E., Chappellaz, J., Dreyfus, G., Fischer, H., Fujita, S., Jouzel, J., Kawamura, K., Lemieux-Dudon, B., Loulergue, L., MassonDelmotte, V., Narcisi, B., Petit, J.-R., Raisbeck, G., Raynaud, D., Ruth, U., Schwander, J., Severi, M., Spahni, R., Steffensen, J. P., Svensson, A., Udisti, R., Waelbroeck, C., and Wolff, E.: The EDC3 chronology for the EPICA Dome C ice core, Clim. Past, 3, 485-497, doi:10.5194/cp-3-485-2007, 2007.

Parrenin, F., Barker, S., Blunier, T., Chappellaz, J., Jouzel, J., Landais, A., Masson-Delmotte, V., Schwander, J., and Veres, D.: On the gas-ice depth difference ( $\Delta$ depth) along the EPICA Dome C ice core, Clim. Past, 8, 1239-1255, doi:10.5194/cp-8-12392012, 2012a.

Parrenin, F., Petit, J.-R., Masson-Delmotte, V., Wolff, E., BasileDoelsch, I., Jouzel, J., Lipenkov, V., Rasmussen, S. O., Schwander, J., Severi, M., Udisti, R., Veres, D., and Vinther, B. M.: Volcanic synchronisation between the EPICA Dome C and Vostok ice cores (Antarctica) 0-145 kyr BP, Clim. Past, 8, 10311045, doi:10.5194/cp-8-1031-2012, 2012b.

Petit, J. R., Jouzel, J., Raynaud, D., Barkov, N. I., Barnola, J.-M., Basile, I., Bender, M., Chappellaz, J., Davis, M., Delaygue, G., Delmotte, M., Kotlyakov, V. M., Legrand, M., Lipenkov, V. Y., Lorius, C., Pépin, L., Ritz, C., Saltzman, E., and Stievenard, M.: Climate and atmospheric history of the past 420000 years from the Vostok ice core, Antarctica, Nature, 399, 429-436, doi:10.1038/20859, 1999.

Raisbeck, G. M., Yiou, F., Jouzel, J., and Stocker, T. F.: Direct north-south synchronization of abrupt climate change record in ice cores using Beryllium 10, Clim. Past, 3, 541-547, doi::10.5194/cp-3-541-2007, 2007. 
Rasmussen, S. O., Andersen, K. K., Svensson, A. M., Steffensen, J. P., Vinther, B. M., Clausen, H. B., SiggaardAndersen, M.-L., Johnsen, S. J., Larsen, L. B., Dahl-Jensen, D., Bigler, M., Röthlisberger, R., Fischer, H., Goto-Azuma, K., Hansson, M. E., and Ruth, U.: A new Greenland ice core chronology for the last glacial termination, J. Geophys. Res.-Atmos., 111, D06102, doi:10.1029/2005JD006079, 2006.

Raynaud, D., Lipenkov, V., Lemieux-Dudon, B., Duval, P., Loutre, M.-F., and Lhomme, N.: The local insolation signature of air content in Antarctic ice. A new step toward an absolute dating of ice records, Earth Planet. Sci. Lett., 261, 337-349, doi:10.1016/j.eps1.2007.06.025, 2007.

Ruddiman, W. and Raymo, M.: A methane-based time scale for Vostok ice, Quat. Sci. Rev., 22, 141-155, doi:10.1016/S02773791(02)00082-3, 2003.

Ruth, U., Barnola, J.-M., Beer, J., Bigler, M., Blunier, T., Castellano, E., Fischer, H., Fundel, F., Huybrechts, P., Kaufmann, P., Kipfstuhl, S., Lambrecht, A., Morganti, A., Oerter, H., Parrenin, F., Rybak, O., Severi, M., Udisti, R., Wilhelms, F., and Wolff, E.: "EDML1": a chronology for the EPICA deep ice core from Dronning Maud Land, Antarctica, over the last 150000 years, Clim. Past, 3, 475-484, doi:10.5194/cp-3-475-2007, 2007.

Salamatin, A. N., Tsyganova, E. A., Lipenkov, V. Y., and Petit, J. R.: Vostok (Antarctica) ice-core time-scale from datings of different origins, Ann. Glaciol., 39, 283-292, doi:10.3189/172756404781814023, 2004.

Schilt, A., Baumgartner, M., Blunier, T., Schwander, J., Spahni, R., Fischer, H., and Stocker, T. F.: Glacial-interglacial and millennial-scale variations in the atmospheric nitrous oxide concentration during the last 800000 years, Quat. Sci. Rev., 29, 182192, doi:10.1016/j.quascirev.2009.03.011, 2010.

Schüpbach, S., Federer, U., Bigler, M., Fischer, H., and Stocker, T. F.: A refined TALDICE-1a age scale from 55 to $112 \mathrm{ka}$ before present for the Talos Dome ice core based on highresolution methane measurements, Clim. Past, 7, 1001-1009, doi:10.5194/cp-7-1001-2011, 2011.

Schwander, J., Barnola, J.-M., Andrie, C., Leuenberger, M., Ludin, A., Raynaud, D., and Stauffer, B.: The age of the air in the firn and the ice at Summit, Greenland, J. Geophys. Res., 98, 2831-2838, doi:10.1029/92JD02383, 1993.

Severi, M., Becagli, S., Castellano, E., Morganti, A., Traversi, R., Udisti, R., Ruth, U., Fischer, H., Huybrechts, P., Wolff, E., Parrenin, F., Kaufmann, P., Lambert, F., and Steffensen, J. P.: Synchronisation of the EDML and EDC ice cores for the last $52 \mathrm{kyr}$ by volcanic signature matching, Clim. Past, 3, 367-374, doi:10.5194/cp-3-367-2007, 2007.

Severi, M., Udisti, R., Becagli, S., Stenni, B., and Traversi, R.: Volcanic synchronisation of the EPICA-DC and TALDICE ice cores for the last $42 \mathrm{kyr}$ BP, Clim. Past, 8, 509-517, doi:10.5194/cp-8509-2012, 2012.

Severinghaus, J. P. and Battle, M. O.: Fractionation of gases in polar ice during bubble close-off: New constraints from firn air $\mathrm{Ne}$, $\mathrm{Kr}$ and Xe observations, Earth Planet. Sci. Lett., 244, 474-500, doi:10.1016/j.eps1.2006.01.032, 2006.

Severinghaus, J. P., Grachev, A., and Battle, M.: Thermal fractionation of air in polar firn by seasonal temperature gradients, Geochem. Geophys. Geosyst., 2, 1048-1024, doi:10.1029/2000GC000146, 2001.
Severinghaus, J. P., Beaudette, R., Headly, M. A., Taylor, K., and Brook, E. J.: Oxygen-18 of $\mathrm{O}_{2}$ records the impact of abrupt climate change on the terrestrial biosphere, Science, 324, 14311434, doi:10.1126/science.1169473, 2009.

Severinghaus, J. P., Albert, M. R., Courville, Z. R., Fahnestock, M. A., Kawamura, K., Montzka, S. A., Mühle, J., Scambos, T. A., Shields, E., Shuman, C. A., Suwa, M., Tans, P., and Weiss, R. F.: Deep air convection in the firn at a zeroaccumulation site, central Antarctica, Earth Planet. Sci. Lett., 293, 359-367, doi:10.1016/j.epsl.2010.03.003, 2010.

Sowers, T., Bender, M., and Raynaud, D.: Elemental and isotopic composition of occluded $\mathrm{O}_{2}$ and $\mathrm{N}_{2}$ in polar ice, J. Geophys. Res., 94, 5137-5150, doi:10.1029/JD094iD04p05137, 1989.

Stenni, B., Buiron, D., Frezzotti, M., Albani, S., Barbante, C., Bard, E., Barnola, J. M., Baroni, M., Baumgartner, M., Bonazza, M., Capron, E., Castellano, E., Chappellaz, J., Delmonte, B., Falourd, S., Genoni, L., Iacumin, P., Jouzel, J., Kipfstuhl, S., Landais, A., Lemieux-Dudon, B., Maggi, V., MassonDelmotte, V., Mazzola, C., Minster, B., Montagnat, M., Mulvaney, R., Narcisi, B., Oerter, H., Parrenin, F., Petit, J. R., Ritz, C., Scarchilli, C., Schilt, A., Schüpbach, S., Schwander, J., Selmo, E., Severi, M., Stocker, T. F., and Udisti, R.: Expression of the bipolar see-saw in Antarctic climate records during the last deglaciation, Nat. Geosci., 4, 46-49, doi:10.1038/ngeo1026, 2011.

Suwa, M. and Bender, M. L.: Chronology of the Vostok ice core constrained by $\mathrm{O}_{2} / \mathrm{N}_{2}$ ratios of occluded air, and its implication for the Vostok climate records, Quaternary Sci. Rev., 27, 10931106, doi:10.1016/j.quascirev.2008.02.017, 2008.

Svensson, A., Andersen, K. K., Bigler, M., Clausen, H. B., DahlJensen, D., Davies, S. M., Johnsen, S. J., Muscheler, R., Rasmussen, S. O., Röthlisberger, R., Peder Steffensen, J., and Vinther, B. M.: The Greenland ice core chronology 2005, 15 $42 \mathrm{kyr}$, Part 2: comparison to other records, Quaternary Sci. Rev., 25, 3258-3267, doi::10.1016/j.quascirev.2006.08.003, 2006.

Svensson, A., Andersen, K. K., Bigler, M., Clausen, H. B., DahlJensen, D., Davies, S. M., Johnsen, S. J., Muscheler, R., Parrenin, F., Rasmussen, S. O., Röthlisberger, R., Seierstad, I., Steffensen, J. P., and Vinther, B. M.: A 60000 year Greenland stratigraphic ice core chronology, Clim. Past, 4, 47-57, doi:10.5194/cp-4-47-2008, 2008.

Svensson, A., Bigler, M., Blunier, T., Clausen, H. B., DahleJensen, D., Fischer, H., Fujita, S., Goto-Azuma, K., Johnsen, S. J., Kawamura, K., Kipfstuhl, S., Kohno, M., Parrenin, F., Popp, T., Rasmussen, S. O., Schwander, J., Seierstad, I., Severi, M., Steffenson, J. P., Udisti, R., Uemura, R., Vallelonga, P., Vinther, B. M., Wegner, A., Wilhelms, F., and Winstrup, M.: Direct linking of Greenland and Antarctic ice cores at the Toba eruption (74 kyr BP), Clim. Past, 9, 749-766, doi:10.5194/cp-9-749-2013, 2013.

Udisti, R., Becagli, S., Castellano, E., Delmonte, B., Jouzel, J., Petit, J. R., Schwander, J., Stenni, B., and Wolff, E. W.: Stratigraphic correlations between the European Project for Ice Coring in Antarctica (EPICA) Dome C and Vostok ice cores showing the relative variations of snow accumulation over the past $45 \mathrm{kyr}$, J. Geophys. Res.-Atmos., 109, D08101, doi:10.1029/2003JD004180, 2004. 
Veres, D., Bazin, L., Landais, A., Toyé Mahamadou Kele, H., Lemieux-Dudon, B., Parrenin, F., Martinerie, P., Blayo, E., Blunier, T., Capron, E., Chappellaz, J., Rasmussen, S. O., Severi, M., Svensson, A., Vinther, B., and Wolff, E. W.: The Antarctic ice core chronology (AICC2012): an optimized multi-parameter and multi-site dating approach for the last 120 thousand years, Clim. Past, 9, 1733-1748, doi:10.5194/cp-9-1733-2013, 2013.

Vinther, B., Clausen, H., Kipfstuhl, S., Fischer, H., Bigler, M., Oerter, H., Wegner, A., Wilhelms, F., Sevri, M., Udisti, R., Beer, J., Steinhilber, F., Adolphi, F., Muschler, R., Rasmussen, S., Steffensen, J., and Svensson, A.: A stratigraphic Antarctic chronology covering the past 16700 years in the EPICA deep ice core from Dronning Maud Land, in preparation, 2013.
Wang, Y., Cheng, H., Edwards, R. L., Kong, X., Shao, X., Chen, S., Wu, J., Jiang, X., Wang, X., and An, Z.: Millennial- and orbitalscale changes in the East Asian monsoon over the past 224000 years, Nature, 451, 1090-1093, doi:10.1038/nature06692, 2008.

Yiou, F., Raisbeck, G. M., Baumgartner, S., Beer, J., Hammer, C., Johnsen, S., Jouzel, J., Kubik, P. W., Lestringuez, J., Stiévenard, M., Suter, M., and Yiou, P.: Beryllium 10 in the Greenland Ice Core Project ice core at Summit, Greenland, J. Geophys. Res., 102, 26783-26794, doi:10.1029/97JC01265, 1997.

Yuan, D., Cheng, H., Edwards, R. L., Dykoski, C. A., Kelly, M. J., Zhang, M., Qing, J., Lin, Y., Wang, Y., Wu, J., Dorale, J. A., An, Z., and Cai, Y.: Timing, duration, and transitions of the Last Interglacial Asian Monsoon, Science, 304, 575-578, doi:10.1126/science.1091220, 2004. 